IZA DP No. 6184

Changes in Job Structure and Rising Wage Inequality in Urban China, 1995-2007

Chunbing Xing

December 2011 


\title{
Changes in Job Structure and Rising Wage Inequality in Urban China, 1995-2007
}

\author{
Chunbing Xing \\ Beijing Normal University \\ and IZA
}

Discussion Paper No. 6184

December 2011

\author{
IZA \\ P.O. Box 7240 \\ 53072 Bonn \\ Germany \\ Phone: +49-228-3894-0 \\ Fax: +49-228-3894-180 \\ E-mail: iza@iza.org
}

\begin{abstract}
Any opinions expressed here are those of the author(s) and not those of IZA. Research published in this series may include views on policy, but the institute itself takes no institutional policy positions.

The Institute for the Study of Labor (IZA) in Bonn is a local and virtual international research center and a place of communication between science, politics and business. IZA is an independent nonprofit organization supported by Deutsche Post Foundation. The center is associated with the University of Bonn and offers a stimulating research environment through its international network, workshops and conferences, data service, project support, research visits and doctoral program. IZA engages in (i) original and internationally competitive research in all fields of labor economics, (ii) development of policy concepts, and (iii) dissemination of research results and concepts to the interested public.
\end{abstract}

IZA Discussion Papers often represent preliminary work and are circulated to encourage discussion. Citation of such a paper should account for its provisional character. A revised version may be available directly from the author. 
IZA Discussion Paper No. 6184

December 2011

\section{ABSTRACT \\ Changes in Job Structure and Rising Wage Inequality in Urban China, 1995-2007}

We use household surveys from 1995, 2002, and 2007 to examine how changes in job structure contributed to China's rising urban wage inequality, considering three job characteristics: occupation, industry, and firm ownership. The explanatory power of job structure for wage inequality increased between 1995 and 2007. Both the change in relative number of jobs (composition effect) and the change in between-job and within-job wage gaps (price effect) contributed to rising wage inequality. Price effect was the major contributor, whereas composition effect played a larger role in the 1995-2002 period than in the 20022007 period, and at the lower-half distribution. Between-job inequality played a major role in the first period, and within-job inequality played a major role in the second period. Our results suggest that both technological change and institutional features influence job structure and wage inequality.

JEL Classification: $\quad$ C21, J31, O15

Keywords: job structure, wage inequality, urban China, decomposition

Corresponding author:

Chunbing Xing

School of Economics and Business Administration

Beijing Normal University

No 19, Xinjiekouwaidajie

Beijing, China, 100875

E-mail: xingchunbing@gmail.com 


\section{Introduction}

Along with the rapidly growing economy, China's urban wage inequality continuously increased in the last two decades (Meng et al., 2010). Higher inequality creates incentive for individuals to invest more in human capital (education and training, for example) and to work harder. Wage inequality may also encourage destructive behavior (crime, for example) and cause social instability. Predicting the possible consequences of rising wage inequality and curing its adverse effects require a good understanding of the factors behind wage inequality. There is a substantial literature analyzing changes in China's urban wage structure (Knight and Song, 2003, 2008; Meng et al., 2010; Liu et al., 2010). This paper explores the role of job structures in urban wage inequality and provides an understanding of the channels through which various factors have affected inequality, considering three dimensions of job heterogeneity: occupation, industry, and ownership.

There are many reasons job-related wage differentials exist. Jobs of different occupations and/or industries may be paid differently because they require specific skills that may or may not be related to education and experience (Autor et al., 2003; Goos and Manning, 2007). ${ }^{1}$ Different working conditions and institutional arrangements can also create occupation and industry wage gaps (Weeden, 2002). In China, workers in different ownerships face different compensation mechanisms and are often paid differently (Dong and Bowles, 2002; Xing, 2008). Finally, there is wage inequality within jobs as well, and the wage gap may vary across jobs because of different distributions of unobserved skills and different compensation mechanisms.

The three dimensions of job heterogeneity (occupation, industry, and ownership) reflect

\footnotetext{
1 See Goos et al. (2009) and Autor et al. (2006) for more recent empirical evidence.
} 
different forces behind wage inequality. Occupation structure and industry adjustment, to a larger extent, reflect the force of technological change, while ownership restructuring displays more of the effect of economic reforms. Because these three aspects were often intertwined in China's transitional process, we define each occupation/industry/ownership cell as one job type.

Wage gaps between and within jobs were small under China's traditional planning system. The transition process, including ownership restructuring and globalization, not only made wage determination more market-oriented, but also facilitated labor reallocations across jobs. A rapid technological progress, which also had a fundamental influence on the job structure by replacing routine human task and increasing demand for non-routine task, accompanied this process. Therefore, investigating detailed changes in the job structure and their contributions to rising wage inequality will provide a more nuanced understanding of how economic and technological forces affected China's inequality, and help us assess their relative importance.

Analyzing urban household surveys from 1995, 2002, and 2007, we find substantial labor reallocations among jobs between 1995 and 2007, with workers moving from the manufacturing sector to the service sector and from the public sector to the private. The results also suggest rapidly increasing wage differentials between jobs in the 1995-2007 period, with managerial and professional jobs earning more than other jobs in 2007 than in 2002 and 1995, and wage gaps between public and non-public sectors increasing significantly by 2007. Quantile regression results indicate that within-job inequalities for different types of jobs were significantly different, and the differential pattern changed over time. Correspondingly, the explanatory power of job structure for wage inequalities increased between 1995 and 2007. 
Finally, we use the reweighting approach developed by DiNardo, Fortin, and Lemieux (1996, hereinafter DFL) to decompose the change in wage inequality into price effect (due to changes in relative wages between and within jobs) and composition effect (due to changes in relative shares of different jobs). Both effects were important contributors to the rising wage inequality, with price effect being relatively more important. Relatively speaking, however, composition effect played a larger role in the 1995-2002 period and was more prevalent at the lower-half wage distribution. Between-job inequality played a larger role in the 1995-2002 period, while within-job inequality played a greater role in the 2002-2007 period.

All results in this paper indicate an important role played by job structure in mediating the influence of technological progress and institutional reforms on the labor market. These results also have major policy implications, which will be discussed later.

This paper proceeds as follows. Section 2 reviews the literature. Section 3 introduces the data and describes how the labor force has been reallocated among jobs over time. Section 4 first examines the explanatory power of job characteristics for wage inequality over time using Fields decomposition (Fields, 2004), and then uses quantile regression technique to investigate changes in relative inequality within jobs. The contribution of job structure to wage inequality is then decomposed into price and composition effects. Section 5 concludes and provides policy implications.

\section{Literature Review}

Recently, economists and sociologists began to explore the relationship between job structure and wage inequality. The literature has found evidence, although mixed, that job structure may influence wage inequality through changes in three aspects: between-job inequality (Mouw and Kalleberg, 2010), within-job inequality (Kim and Sakamoto, 2008), 
and job composition, or polarization effect (Autor et al., 2003; Goos and Manning, 2007; Goos et al., 2009; Autor et al., 2006).

Goos and Manning (2007) argue that technological progress will raise relative demand in well-paid skilled jobs (professional and managerial jobs, for example) and in low-paid unskilled jobs, and reduce the relative demand in "middle" jobs. The reason is that technology can easily replace "middle" jobs involving routine tasks, but cannot replace human labor in non-routine (both highly skilled and manual) tasks (Autor et al., 2003). We conclude from these studies that job structure is an essential channel through which basic technological forces influence the labor market. Although the above researches were on western countries: US, UK, and other OECD countries, our paper belongs to this literature but in the context of transitional China, where institutional features also play a big role.

Our paper also reflects a growing literature on the wage structure of urban China, but the most extensively studied issue seems to be the relationship between wage levels and education and experience, based on the seminal work of Mincer (1974). Basic findings show that the returns to education (or skill prices) for urban China have increased continuously since the late 1980s (Zhang et al., 2005), and that the rising skill prices could explain most of the increase in wage inequality (Li et al., 2007). Studies are also trying to uncover factors behind the skill prices (Liu et al., 2010), but the attention paid to job structure is inadequate. As job choices are often correlated with human capital levels, the increase in skill prices may take the form of increased wage differentials between jobs.

As mentioned in the introduction, job structure may influence wage levels and wage inequality even after controlling for general skill levels. It is not an uncommon practice in researches to control for occupation, industry, and/or ownerships when examining wage 
determination, but more often, these characteristics are auxiliary control variables, and how these characteristics affect wages is seldom reported.

With the enlargement of the private sector in the urban sector since the early 1990 s, more workers were paid according to their performance and unobserved (at least to researchers) skills. Even in public sectors, employees were increasingly paid based on performance in recent years. Consequently, within-job inequalities might be a factor behind the wage inequality increase that occurred when skill prices increased. However, the research on within-job inequalities' contribution to rising wage inequality is still scarce, Knight and Song (2008) being an exception. They used quantile regression to examine relative withingroup inequalities and their changes between 1995 and 2002, and found that unobserved characteristics "appear to fetch a higher market price."

Knight and Song (2008) also found that occupation played an important role in the increasing wage inequality between 1995 and 2002. We go one step further in decomposing the effect of changing job structure into price effect and composition effect, the price effect being further decomposed into within-job and between-job effects. This approach has not yet been investigated in the literature.

One small literature that pays particular attention to job structure is that of researches on gender income gap. There are a few studies emphasizing occupational segmentation in China (Meng and Miller, 1995; Meng, 1998; Meng and Zhang, 2001 for instance), but gender income gap literature directly exploring the relationship between job structure and inequality is rare.

\section{Data}

We use data from China Household Income Project (CHIP) surveys for 1995, 2002, and 
2007 to examine the effect of job structure change on wage inequality. In using the CHIP data, we gather information on observations aged 18-60. The CHIP data is known for its high quality and national representativeness. In 1995 and 2002, the survey collected information in Beijing, Shanxi, Liaoning, Jiangsu, Anhui, Henan, Hubei, Guangdong, Sichuan, Chongqing, ${ }^{2}$ Yunnan, and Gansu. More provinces (Shanghai, Zhejiang, Fujian, and Hunan) were included in the 2007 survey, but they were not included in our analysis for the sake of comparability.

Table 8 in the Appendix shows the regional distribution of observation numbers and the economic structure in each region. In 1995,2002 , and $2007,37 \%, 39 \%$, and $42 \%$ of the observations were distributed in eastern areas, respectively, showing agglomeration of the labor force in those regions and that these regions outperformed hinterland China. The economic structures were also different, with the east having a larger share of the tertiary industry. Although regional inequality is an important dimension, a full study of this topic is beyond the scope of this paper. Instead, we control for province dummies in most of our regressions to account for regional variation; thus, the results can be assessed as the average across regions.

Because the sampling process of these surveys was based on formal residence registration (hukou), the data we use exclude most migrant households without formal residence permits in urban areas. Considering the large amount of rural-to-urban migrants (Cai et al., 2009), and that they are usually worse off than urban local workers (Démurger et al., 2009), our data may produce biased urban inequality; however, by focusing on a subsample with urban hukou, there is less need to consider the monetary value of hukou. If, instead, both native and migrant workers were considered, neglecting hukou value would bias

\footnotetext{
${ }^{2}$ Chongqing was a city of the Sichuan province before 1997; after 1997 it became a direct-control city.
} 
urban inequality because several benefits come with hukou status. ${ }^{3}$ Due to the lack of data on migration and the complication of hukou value, it is difficult to assess to what extent our data bias urban inequality. The findings in this paper should therefore be interpreted with these caveats in mind.

This paper choosing to analyze annual rather than hourly wage also merits some discussion. The surveys in 1995 and 2002 collected working time information. Summary statistics of working time for these years, shown in Table 9 in the Appendix, suggest that workers in 2002 worked longer than those in 1995 . There are also variations in working time across jobs, but the differentials are not large. Unfortunately, the data for 2007 do not have working time; therefore, we use annual wages in our paper.

Another reason for using annual wages is that some labor income may only come to the worker at the end of a year (for example, a bonus). The wage data in the CHIP include two parts: regular wages and "other labor income." The latter part includes bonus and subsidies. Overtime and other compensations are accounted for as long as they are "labor income" and the wage data were not top-coded. All wages are deflated to 1995 RMB prices using the national CPI.

As mentioned, job categories are defined based on occupational type, industry, and ownership. There are six occupation types: managerial (head or unit head), professional, ordinary staff, unskilled worker, skilled worker, and other. These occupations are distributed in 13 industries. Workers can also be in different ownerships: state-owned enterprises (or SOEs), collective enterprises, and other ownerships. Other ownerships, hereafter referred to as "private sector," include joint-owned enterprises, foreign enterprises, and private firms;

\footnotetext{
${ }^{3}$ The bias can be in either direction. One scenario is that people with urban local hukou have higher wages, possibly because of discrimination against migrant workers. On the other hand, people may accept lower wages because their urban hukou guarantees other benefits. For a more detailed discussion of China's hukou system, see Fan (2008).
} 
therefore, the heterogeneity within this group is large. In particular, foreign firms may have higher productivity and pay higher wages. It would be ideal if we had enough observations for workers in such firms; unfortunately, the number of observations in foreign or joint ventures is small for 1995 and $2002,{ }^{4}$ and we cannot identify such ownerships in the data for 2007. Finally, we have 234 ownership-industry-occupation jobs.

Table 1 reports summary statistics. Both wage level and wage inequality increased between 1995 and 2007. Log annual wages increased from 8.53 in 1995 to 9.02 in 2002, and to 9.50 in 2007. Standard deviation increased from 0.69 in 1995 to 0.76 in 2002, and to 0.82 in 2007. Inequality increased more on the upper half of wage distribution in the 2002-2007 period. This pattern is also found in other researches (Xing, 2010).

\section{(Insert Table 1 around here)}

Significant changes in job composition accompanied the increase in wage inequality. For convenience, we look at three dimensions of job heterogeneity separately to see these changes. ${ }^{5}$ As for occupation, there are gradual decreases in managerial and professional jobs, while the share of ordinary staff increased dramatically between 2002 and 2007. In a period of rising skill prices, these findings sound counterintuitive and inconsistent with evidence from developed countries. This may be due to the ambiguity of occupation definitions. Another possible reason is that the labor force was increasingly reallocated from SOEs to the private sector. The SOEs tend to be larger and more hierarchical, and therefore have more unit heads. There are also more rigid employee rankings based on seniority and/or education levels. In the private sector, however, more workers are likely to be classified as "ordinary

\footnotetext{
4 See Table 10 of the appendix. Even with a small number of observations in the foreign sector, we can tell that the manufacturing industry and the trade and commercial industry have relatively more workers in foreign firms.

${ }^{5}$ Considering a full set of jobs $(13 * 6 * 3=234$ categories $)$ requires a lot of space, and the payoff is marginal. In the Fields decomposition analysis later, we will consider a full set of job categories and the results are similar.
} 
staff."

Changes in industry composition provide a more accurate picture of the changing job structure. In 1995, over $40 \%$ of the workforce was in the manufacturing industry. By 2007 , this workforce declined to $20 \%$. This is consistent with the hypothesis that technological change can replace routine human tasks and complement non-routine human labor. Because work in the manufacturing industry involves a large amount of routine tasks, machines and computers, with the rapid progress of computer science and the sharp price decrease in computing tasks, could easily replace manufacturing jobs. Also consistent with this hypothesis, the labor force was increasingly absorbed by the IT and service industry, where the tasks were not easy to replace by computers. The share of employees in the government also increased slightly.

Associated with changes in job structure, education levels increased as well. The average years of schooling increased from 10.8 in 1995 to 11.5 in 2002, and to 12.8 in 2007 . The average years of experience for the workforce increased from 19.5 years in 1995 to 21.7 in 2007.

\section{Job Structure and Wage Inequality}

\subsection{Jobs and Wage Determination}

We estimate wage equations for each year to see the changes in between-job wage differentials. $^{6}$ Before that, we estimate wage equations controlling only for years of schooling, experience, experience squared, sex, and province dummies. The first three columns of Table 2 report these results. Each additional year of schooling was associated

\footnotetext{
${ }^{6}$ We use OLS or quantile regressions to estimate wage equations, for which the omitted variable (ability) problem is a textbook example of an endogeneity problem; however, we do not endeavor to address this problem, mainly because our focus is to explain wage variations rather than to establish a causal relationship between two variables. Also, there is no consistent evidence showing that OLS estimates are systematically different from the estimates using IVs or other empirical strategies (Card, 1999). As a result, running OLS for wage equations seems to be an accepted practice in our profession (see Knight and Song, 2003, 2008; Meng et al., 2010; Lemieux, 2006; Lemieux et al., 2009, for examples).
} 
with a $5 \%$ increase in wages in 1995 . This association increased to over $8 \%$ and nearly $12 \%$ in 2002 and 2007, respectively. Women earned significantly less than men did, and the gap enlarged significantly, especially for the 2002-2007 period. As in many other studies, the explanatory power of these variables is small (the adjusted R-squared are below 30\%).

\section{(Insert Table 2 around here)}

Columns 4-6 of Table 2 report the results with controls for job characteristics. The adjusted R-squared and the explanatory power of the model increased after adding job-related variables. The fact that the coefficients for education decrease in these results indicates that job characteristics are correlated with education. We thus explore the variations caused by job characteristics holding education and experience constant; that is, we investigate the inequalities caused by job characteristics for individuals with the same level of education. ${ }^{7}$

Coefficients for occupation dummies were negative, meaning the managerial jobs (the omitted group in regression) received the highest pay in all three years. Professional jobs had the second highest pay. In 1995, the wage differential between managerial and professional jobs was insignificant. The unskilled workers had the lowest wage levels.

Wage differentials between occupations increased in the latter two survey years. The managerial jobs began to have significantly higher wages than professional jobs and to earn higher than other jobs by a larger margin. The wages of ordinary staff were $12 \%$ lower than that for managerial positions in 1995. The gap increased to $16 \%$ in 2002 and to $18 \%$ in 2007 . Meanwhile, the wage levels of unskilled workers were $26 \%$ lower than that for managerial positions, and it increased to around 40\% lower in 2002 and 2007. The rising gap between

\footnotetext{
${ }^{7}$ Another exercise we will do in "Decomposing Changes in Wage Inequality," is decomposing residual wage inequality (the wage regressions are using log of wage as dependent variable and education, experience, experience squared, gender, and province dummies). These exercises differentiate out the between-group variation due to education and experience.
} 
different occupations, again, reflects the influence of technological change as suggested by Goos and Manning (2007) and Autor et al. (2003): while computers easily replace ordinary staff and unskilled workers, managerial jobs or professional jobs require more creative thinking and personal skills, skills whose demand increases with technological progress. Furthermore, as the managerial and professional jobs are at the top of job ladders, and the "ordinary staff" or "ordinary workers" belong to the traditional "middle class," changes in relative wages mean that the gaps in the upper-half wage distribution will increase. This partially explains why the upper-half wage distribution increased more significantly in recent years.

These above forces were also at work in shaping the wage differentials across industries. Compared to the manufacturing industry (the omitted group), workers in high-tech industries earned higher wages, as did workers in finance and insurance industries. Service workers in the catering and restaurant industry earned lower wages.

The industry wage differentials evolved over time. Workers in the mining industry earned significantly higher in 2007 than in previous years, which may be due to the rising demand for energy in recent years. Given the unhealthy working conditions and high risk of losing lives or being injured, it seems reasonable that workers with the same personal characteristics demand higher wages to work in this industry. We also find that industries of health, physical culture, social welfare, education, culture, and arts and broadcasting (industry 7 and 8 in Table 2) had much higher wages in 2002. We conjecture that the education expansion in the late 1990s, which increased the demand for such services, might have caused the spikes in these industries. Another possible reason is that jobs were more secure in those industries and workers there did not suffer massive unemployment or layoff in the late 1990s ownership restructuring, at least compared to the manufacturing industry. After 
some adjustment, both in these industries and manufacturing industries, the wage differentials tended to diminish by 2007. We admit, however, these reasons are speculative and more concrete evidence is needed.

Firm ownerships also have significant impact on wages. In all three years, workers in collective sectors earned significantly lower than those in the SOEs (the omitted group), indicating a bifurcation within the public sector. Of special interest is the wage differential between the private sector and the SOEs. In 1995, the private sector had slightly higher wages than the SOEs, but the difference was not significant. In 2002 and 2007, however, workers in the private sector earned significantly lower than workers in SOEs did, by about $20 \%$ and $30 \%$, respectively. This is a strong indication that the performance and the wage setting behavior had changed for the SOEs after the late 1990s ownership restructuring.

Besides these changes in the public sector, the enlarging gap may also be due to the slow wage growth in the private sector. First, the late 1990s ownership restructuring created a large number of laid-off or unemployed workers, and the private sector absorbed the majority of these workers. Second, urban workers in the private sector were more likely to face competition from rural-urban migrants, while workers in SOEs were more immune to such competitions.

The 1995 and 2002 surveys also collected position or ranking information about jobs. There were four levels in professional jobs: ordinary technician and junior, middle, and senior level professionals. There were also four parallel levels for managerial jobs. Employees with higher education levels and those in the public sector were more likely to be subject to this ranking system. Employees with these titles (other than ordinary staff) had higher wages than those without (see columns 1 and 2 of Table 3 ). 
Not surprisingly, higher-level titles were associated with higher wages. Between 1995 and 2002, the differential increased sharply. Columns 3 and 4 of Table 3 report the results employing restricted samples retaining only employees with titles. Junior and middle level professional jobs earned $17 \%$ and $10 \%$ lower than the senior ones in 1995 . By 2002 , the gaps increased to $27 \%$ and $15 \%$, respectively. Gaps along the administrative track also enlarged during this period.

\subsection{Contribution of Job Structure to Wage Inequality: Fields Decomposition}

To see the contribution of job structure to wage inequality, we decompose the wage variation into various parts according to the following formulas (Fields, 2004):

$$
\begin{aligned}
& s\left(X^{k}\right)=\frac{\operatorname{cov}\left[X^{k} \hat{\beta}^{k}, Y\right]}{\operatorname{var}(Y)} \\
& s(\hat{\varepsilon})=\frac{\operatorname{cov}[\hat{\varepsilon}, Y]}{\operatorname{var}(Y)}
\end{aligned}
$$

where $X^{k}$ is the $\mathrm{k}^{\text {th }}$ variable, $\hat{\beta}^{k}$ is the estimated coefficient for $X^{k}$ in wage equations, and $\hat{\varepsilon}$ is the predicted residual. The decomposition results are reported in Table 4.

\section{(Insert Table 4 around here)}

Job structure played an important role in all three years. In 1995, job structure could explain $7.4 \%$ of the variance in log wages, while region and experience explained $11.3 \%$ and $8.3 \%$, respectively. Job structure's explanatory power reached $16.1 \%$ in 2002 , becoming the most important in explaining the wage variation. It decreased to $12 \%$ in 2007 , but maintained 
the highest explanatory power among all factors. Moreover, different dimensions of job heterogeneity played different roles. Occupation type played a major role in 1995 and 2002, and there was a sharp increase in its explanatory power between these two years. The contribution of ownership increased continuously, and by 2007 , its explanatory power $(5.4 \%)$ had surpassed that of occupation (4.8\%). Industry played a relatively small role among these three dimensions.

Along with the changes in the contribution of job structure to wage variations, that of other variables also changed. Education could explain only $2 \%$ of the wage variation in 1995. By 2002 , its explanatory power reached $4.7 \%$, and by $2007,8.7 \%$. In other words, education contributed to increases in wage inequality. Gender also became an increasingly important contributor to wage inequality. The explanatory power of experience (or seniority), however, kept decreasing from $8.3 \%$ in 1995 to $4.2 \%$ in 2002 , and to $1.7 \%$ in 2007 .

We also run wage regressions controlling for a full set of job categories instead of controlling for only occupation, industry, and ownership dummies. The Fields decomposition results are reported in panel B of Table 4 . The explanatory powers of job structure, as well as the model, increase because more between-job inequality is captured. In 2002, over one half of the explanatory power of the model came from job characteristics. The patterns in panel B are similar to those in panel A.

Adding ranking information into wage equations increased the explanatory power, but only marginally. Ranking, or job title, seems to have contributed to the rising wage inequality (see columns 1-4 of Table 5). For restricted samples with job titles, job title played an even bigger role. In $2002,15 \%$ of the model's explanatory power came from job titles, only less than that from region, which was $48 \%$ (see column 8 of Table 5 ). 
4.3 Within-Job Inequality: Evidence from Quantile Regressions

OLS regressions of wage equations describe how wages differ between jobs on average. Quantile regressions at various percentiles give a more detailed description of the conditional distribution of wages. If quantile regressions give estimates that are not significantly different across percentiles, it is more probable that the within-job wage distributions are identical. Otherwise, different jobs are associated with different inequalities. Results from different years show how relative within-job inequalities changed over time. An important finding in Table 6, therefore, is that within-job inequalities for different jobs were different and the pattern changed between 1995 and 2007.

Taking managerial jobs as a reference group, unskilled workers earned $38 \%$ less at the $10^{\text {th }}$ percentile of the conditional wage distribution. The regressions at the $50^{\text {th }}$ and $90^{\text {th }}$ percentiles gave results of $-20 \%$ and $-15 \%$, revealing that unskilled workers earned less than managerial jobs and the gap was larger at a lower wage than at a higher wage. ${ }^{8}$ This result indicates that within-job inequality for unskilled workers was larger than that for managerial jobs.

\section{(Insert Table 6 around here)}

In 2007 , the coefficient for unskilled workers was still -0.38 in the $10^{\text {th }}$ percentile quantile regression, but the gap in the $50^{\text {th }}$ and $90^{\text {th }}$ percentile regressions $(-0.36$ and -0.30 , respectively) was larger than in 1995. Therefore, either within-group inequality for skilled workers decreased or that for managerial jobs increased, or both. The magnitude of coefficients was not necessarily monotonic in percentiles as indicated by coefficients for the

\footnotetext{
8 Wage levels here refer to positions on conditional wage distributions.
} 
same variable (unskilled workers for example) in 2002.

For skilled workers, the results also indicate that within-group inequality was larger than that for managerial jobs in both 1995 and 2007. The changes in coefficients for this period are evenly distributed across various percentiles. For the $10^{\text {th }}$ percentile quantile regression, the coefficient decreased from -0.17 in 1995 to -0.30 in 2007 . The extents of decreases are about the same as those for coefficients at the $50^{\text {th }}$ and $90^{\text {th }}$ percentiles. The whole wage distribution for skilled workers moved to a lower position, but there was no significant change in relative inequality between the skilled workers and managerial jobs.

Quantile regressions also give more information on wage differentials between ownerships. In 1995, at the bottom of conditional wage distribution, workers in SOEs earned more than those in the private sector did, but the difference is insignificant. In upper positions $\left(50^{\text {th }}\right.$ and $90^{\text {th }}$ percentiles), however, workers in private sectors had significantly higher wages than those in SOEs. These results indicate that private sectors had performed better in general and had more dispersion in wage distribution by the mid-1990s.

Coefficients for the private sector in various quantile regressions turned negative in 2002. The difference at the upper position was smaller, which still means that the wage dispersion within the private sector was larger. The SOEs performed even better in 2007, and the wage gap at the upper positions enlarged, an indication that inequality within the SOEs had increased. Because the coefficients in these regressions show relative difference in wage levels between different ownerships, this result may also mean that the inequality in the private sector had decreased; however, we have not found evidence in support of this hypothesis. Instead, the CHIP data show an increased rather than decreased Gini coefficient: 0.388 in 1995, 0.406 in 2002, and 0.409 in 2007 . 
Different job ranks also had different within-group inequalities (see Table 3). The results for 1995 indicate that professional or managerial jobs of different seniority levels had less wage dispersions than the reference group (those without ranks or titles). This changed for some groups in 2002. The senior professional workers for instance, seemed to have larger within-group inequality in 2002 , as the wage gaps between the senior professional workers and the reference groups were larger at higher wages than at lower wages. The within-group inequality for middle level professional jobs also increased relatively.

\subsection{Decomposing Changes in Wage Inequality: Price Effect and Composition Effect}

This subsection addresses the contributions of changes in relative number of jobs (composition effect) and relative wages between and within jobs (price effect) to the increase in wage inequality. We construct a series of counterfactual wage inequalities using the DFL approach, which can be used to hold job characteristics constant over time.

To assess the contribution of the price effect to the increase in wage inequality between 1995 and 2002, we calculate a counterfactual inequality that would have prevailed in 2002 if the distribution of job characteristics were as in 1995. The difference between this counterfactual inequality (a combination of 2002 price structure and 1995 job composition) and the actual one of 1995 (a combination of 1995 price structure and 1995 job composition) was price effect. Using DFL, the above counterfactual can be obtained by reweighting the wage data in 2002 to reflect the changes in job characteristics between 1995 and 2002. We first run a probit model of $\operatorname{Pr}(Y 1995 \mid X)$ using data in 1995 and 2002, in which Y1995 equals one if the observation belongs to 1995 and zero otherwise, and $\mathrm{X}$ is a vector of job categories. Then we predict a weight for each observation in 2002 using the formula $\hat{\operatorname{Pr}}[Y 1995 \mid X] /[1-\operatorname{Pr}[Y 1995 \mid X]]$, which is used to calculate counterfactual wage inequality. 
Take manufacturing workers for example: $X=$ manuf. We would give 2002 observations with manufacturing jobs higher weight when calculating counterfactual inequality because there were more manufacturing jobs in 1995 than in 2002. This is exactly the role played by the weight $\operatorname{Pr}[Y 1995 \mid$ manuf $] /[1-\operatorname{Pr}[Y 1995 \mid$ manuf $]] .9$

Row 1, column 2 of Table 7 is the counterfactual inequality of d9010 (differential between the $90^{\text {th }}$ and $10^{\text {th }}$ percentiles) in 2002 , with job characteristics held at the 1995 level. The elements in row 1, column 1, and row 2, column 2 are the actual inequalities for 1995 and 2002, respectively. The change in d9010 between 1995 and 2002 totaled 0.22 $(=1.653-1.433), 73 \%$ of which was due to changes in relative wages $(=(1.593-1.433) / 0.22)$, and $27 \%$ due to composition effect. Actual and counterfactual inequality measures of d5010 and $\mathrm{d} 9050$ are also reported in Table 7 . At the lower-half (d5010), the inequality increase between 1995 and 2002 totaled $0.114,55 \%$ of which was due to price effect, while at the upper half the increase in inequality totaled $0.107,92 \%$ of which was due to price effect.

We also construct counterfactuals for inequalities in 2007, holding job characteristics constant at the 2002 level (for example, row 2, column 3 is a counterfactual d9010). From 2002 to 2007 , the increase in $\mathrm{d} 9010$ was 0.225 , and over $70 \%$ of the increase was concentrated at the upper half. Price effect played a major role at both the upper and lower half of the wage distribution, accounting for about $87 \%$ of the increase in inequality.

Alternative counterfactuals can be constructed. Row 2, column 1, for example, is a counterfactual d9010 using 1995 wage data and reweighting them to resemble the 2002 job composition. The decomposition calculation shows that the composition and price effects between 1995 and 2002 were 45\% and 55\%, respectively. Decompositions at different parts

\footnotetext{
${ }^{9}$ See DiNardo et al. (1996) for technical details.
} 
of the wage distribution (d5010, d9050) show similar results, with price effect being around $45 \%$. We also construct counterfactuals using 2002 wage data and reweighting them to resemble 2007 job composition (elements in column 2, rows 3, 6, and 9). Three quarters of the increase in d9010 was due to price effect, and the price effect was larger at the upper half of the wage distribution.

\section{(Insert Table 7 around here)}

Although alternative counterfactuals produce different results, some general patterns emerge. Both composition change and changes in relative wages between and within jobs contributed to the rising wage inequality. Relatively speaking, composition effect played a more important role in the 1995-2002 period and was more important at the lower-half wage distribution, while price effect played a major role in the 2002-2007 period and was more important at the upper-half wage distribution.

Price effect comes from two sources: the wage gaps between jobs and within jobs. We examine the relative importance of these two gaps through an approach using the hybrid of variance decomposition and reweighting (see Lemieux et al., 2009). The results are reported in panel $\mathrm{E}$ and $\mathrm{F}$ in Table 7. Between 1995 and 2002, most of the increase in variance was due to increase in between-job inequality. The total increase was 0.103 and the increase in between-job variance was 0.075 . The decomposition results were highly dependent on how the counterfactuals were constructed. For the 2002-2007 period, within-job inequality played a predominant role, for which $38 \%$ or $68 \%$ was due to price effect, depending on how the counterfactuals were constructed.

Instead of using log wage directly, columns 4-6 use the residuals of log wages to purge out the effect of changes in demographic variables. We first run regression of log wage on 
schooling years, experience, experience squared, sex, and province dummy variables, and then predicted wage residuals. The actual and counterfactual inequalities are calculated similarly. All the inequality measures decreased significantly, but the patterns we observe in columns $1-3$ remain. ${ }^{10}$

The decomposition findings in this subsection appear consistent with the timing and contents of major events in China's transitional process. First, a relatively larger composition effect in the 1995-2002 period echoes major reforms in the late 1990s when many SOEs were privatized. The private sector subsequently absorbed a large number of laid-off or unemployed workers and transferred them to other occupations or industries.

Second, several major events or forces can explain the rise in skill price in both the 1995-2002 and 2002-2007 periods: (1) Ownership restructuring made the wage setting behavior more market-oriented as more workers were now in the private sector and as wage gaps within different sectors (especially in the SOEs) enlarged. ${ }^{11}$ (2) Technological progress increased the demand for non-routine skilled workers. (3) Greater openness increased China's involvement in the globalized production process and increased demand for skilled labor. In particular, in the 2002-2007 period, when China was already a member of WTO, China experienced a sharp increase in the ratio of export over GDP, increasing from $22 \%$ in 2002 to 36\% in 2007 (NBS, 2009). Along with rapid export growth, China's exports became more sophisticated, with resources moving from agriculture and textiles into machinery,

\footnotetext{
${ }^{10}$ Table 11 in the appendix reports the decomposition results for men and women. The results by gender suggest similar conclusions to the ones with the pooled sample. Although there is a difference between genders, it is difficult to detect consistent differential patterns. We therefore choose to contend with the pooled sample results and leave a detailed gender differential study for future research.

11 The employment share in SOEs decreased from $59 \%$ in 1995 to $29 \%$ in 2002 . The decrease was dramatic immediately after the $15^{\text {th }}$ National Congress of the Communist Party of China in 1997. From 1997 to 1998 SOE employment share decreased by 11\%. This decreased more gradually between 2002 and 2007 (from 29\% to 22\%) (NBS, 2009).
} 
electronics, and assembly (Amiti and Freund, 2008). ${ }^{12}$ This force tended to increase demand for skilled labor and drive up skill prices. ${ }^{13}$

\section{Discussion and Conclusions}

Job structure in terms of occupation, industry, and ownership changed significantly between 1995 and 2007. In this paper, we use three Chinese urban household surveys for 1995, 2002, and 2007 to evaluate how these changes affected China's urban wage inequality. A series of statistical exercises (OLS/quantile regression, Fields decomposition, and DFL decomposition) suggest that job structure has a substantial effect on wage inequality and it is an important channel through which more fundamental forces influence the labor market and wage inequality.

Our results also convey that China's rising wage inequality is the result of several forces working together. First, we can conclude that technological progress was a fundamental force, without which a large proportion of the job structure change would not have happened. By focusing on job structure, we can have a closer look at how technological change affected the labor market. In particular, the job structure change suggests that technological change played a role in substituting the routine task jobs and in complementing the non-routine task jobs. The role played by technological change has a clear policy implication. In an information age, creative thinking and personal skills are more important than mechanic (routine) skills. The former skills should be emphasized in our education and training programs. Otherwise, we may risk losing our middle class.

Institutional factors were equally important. One important finding of this paper is that

\footnotetext{
${ }^{12}$ China also witnessed a broadening of globalization in the 1990s. Wan et al. (2007) gave a brief description on China's journey to globalization through trade and tourism, foreign investment, and movement of people, but Branstetter and Lardy (2006) argue that accession into WTO was a watershed in China's globalization process.

${ }^{13}$ See Goldberg and Pavcnik (2007) for a detailed discussion of why openness can influence skill prices.
} 
ownership structure is an increasingly important contributor to wage inequality. This is partly because wage inequality in the public sector has increased. Another aspect is that many SOEs enjoy monopolistic power, and workers in this sector earn significantly higher wages than those in the private sectors do. These findings echo public concern about the monopolistic power of SOEs. We hope this paper can provide some empirical evidence for pushing SOE reforms forward.

Acknowledgements I thank Chuliang Luo for the help in using CHIP data, John Whalley for very helpful discussions, and three referees for very constructive comments. Financial support from the National Natural Science Foundation of China (No. 71103019) is acknowledged.

\section{References}

Amiti M, Freund C (2008). An anatomy of China's export growth. NBER Working Paper

Autor D H, Katz L F, Kearney M S (2006). The polarization of the U.S. labor market. American Economic Review, 96(2): 189-94

Autor D H, Levy F, Murnane R (2003). The skill-content of recent technological change: an empirical investigation. Quarterly Journal of Economics, 118(4): 1279-1333

Branstetter L, Lardy N (2006). China's embrace of globalization. NBER Working Paper, No. 12373

Cai F, Du Y, Wang M (2009). Migration and Labor Mobility in China. UNDP Human Development Research Paper 2009/09

Card D (1999). Causal effects of education on earnings. In: Orley Ashenfelter and David Card (eds.), Handbook of Labor Economics, Elsevier

Démurger S, Gurgand M, Li S, Yue X (2009). Migrants as second-class workers in urban China? a decomposition analysis. Journal of Comparative Economics, 37(4): 610-628

DiNardo J, Fortin L, Lemieux T (1996). Labor market institutions and the distribution of wages, 1973-1992: a semi-parametric approach. Econometrica, 64 (5): 1001-1044

Dong X, Bowles P (2002). Segmentation and discrimination in China's emerging industrial labor market. China Economic Review, 13: 170-196

Fan C (2008). China on the move: migration, the state, and the household. Routledge, London and New York

Fields G (2004). Regression-based decompositions: a new tool for managerial decisionmaking. Working Paper, Department of Labor Economics, Cornell University

Goldberg P, Pavcnik N (2007). Distributional effects of globalization in developing countries. Journal of Economic Literature, 45(1): 39-82

Goos M, Manning A (2007). Lousy and lovely jobs: the rising polarization of work in Britain," Review of Economics and Statistics, 89:118-33

Goos M, Manning A, Salomons A (2009). Job polarization in Europe. American Economic Review: Papers \& Proceedings, 99(2): 58-63

Kim C, Sakamoto A (2008). The rise of intra-occupational wage inequality in the United States, 1983 to 2002. American Sociological Review, 73:129-57 
Knight J, Song L (2003). Increasing urban wage inequality in China: extent, elements and evaluation. Economics of Transition, 11(4): 597-619

Knight J, Song L (2008). China's emerging urban wage structure, 1995-2002. In: Gustafsson B, Li S, Sicular T (eds.), Inequality and public policy in China, Cambridge University Press, 221-242

Lemieux T (2006). Increasing residual wage inequality: composition effects, noisy data, or rising demand for skill. American Economic Review, 96: 461-98

Lemieux T, MacLeod W B, Parent D (2009). Performance pay and wage inequality. Quarterly Journal of Economics, 124(2): 1-49

Li X, Zhao Y, Lu L (2007). Effects of education on wage inequality in urban China, 1988-2003. The $6^{\text {th }}$ PEP Research Network General Meeting

Liu X, Albert P, Zhao Y (2010). Explaining rising returns to education in urban China in the 1990s. IZA Discussion Paper 4872

Meng X (1998). Gender occupational segregation and its impact on the gender wage differential among rural-urban migrants: a Chinese case study. Applied Economics, 30(6): 741-752

Meng X, Miller P (1995). Occupational segregation and its impact on gender wage discrimination in China's rural industrial sector. Oxford Economic Papers, 47:136-155

Meng X, Zhang J (2001). The two-tier labor market in urban China: occupational segregation and wage differentials between urban residents and rural migrants in Shanghai. Journal of Comparative Economics, 29(3): 485-504

Meng X, Shen K, Sen X (2010). Economic reform, education expansion, and earnings inequality for urban males in China, 1988-2007. IZA Discussion Paper No. 4919

Mincer J (1974). Schooling, experience, and earnings. New York: NBER

Mouw T, Kalleberg A (2010). Occupations and the structure of wage inequality in the United States, 1980s to 2000s. American Sociological Review, 75: 402-431

NBS (National Bureau of Statistics of China) (2009). China Statistical Yearbook. China Statistics Press, Beijing.

Wan G, Lu M, Chen Z (2007). Globalization and regional income inequality in China, empirical evidence from within China. Review of Income and Wealth, 53(3): 35-59

Weeden K (2002). Why do some occupations pay more than others? Social closure and earnings inequality in the United States. American Journal of Sociology, 108:55-101

Xing C (2008). Human capital and wage determination in different ownerships, 1989-97. In: Wan G (ed.), Understanding inequality and poverty in China: methods and applications. Palgrave Macmillan, 117-135

Xing C (2010). Residual wage inequality in urban China, 1995-2007. IZA Discussion Paper 5003

Zhang J, Zhao Y, Park A, Song X (2005). Economic returns to schooling in urban China, 1988 to 2001. Journal of Comparative Economics, 33: 730-752 
Table 1 Summary Statistics

\begin{tabular}{|c|c|c|c|}
\hline Variable & $\begin{array}{c}1995 \\
(1)\end{array}$ & $\begin{array}{c}2002 \\
(2)\end{array}$ & $\begin{array}{c}2007 \\
\text { (3) }\end{array}$ \\
\hline Years of schooling & 10.79 & 11.52 & 12.81 \\
\hline Experience (age - years of schooling -6 ) & 19.51 & 20.36 & 21.71 \\
\hline Female & 0.47 & 0.44 & 0.45 \\
\hline \multicolumn{4}{|l|}{ Occupation } \\
\hline Managerial (Head/Unit Head) & 0.12 & 0.11 & 0.05 \\
\hline Professional & 0.23 & 0.22 & 0.19 \\
\hline Ordinary Staff & 0.21 & 0.21 & 0.35 \\
\hline Unskilled Worker & 0.17 & 0.22 & 0.17 \\
\hline Skilled Worker & 0.22 & 0.20 & 0.19 \\
\hline Others & 0.05 & 0.04 & 0.04 \\
\hline \multicolumn{4}{|l|}{ Industry } \\
\hline Manufacturing & 0.42 & 0.26 & 0.20 \\
\hline Mining and geological survey and prospecting & 0.01 & 0.02 & 0.01 \\
\hline Construction & 0.03 & 0.03 & 0.03 \\
\hline Transportation, communications, posts and telecommunications & 0.05 & 0.08 & 0.10 \\
\hline Commerce and trade, restaurants \& catering, materials supply & 0.14 & 0.10 & 0.14 \\
\hline Real estate, public utilities, personal and consulting services & 0.04 & 0.14 & 0.17 \\
\hline Health, physical culture and social welfare & 0.05 & 0.05 & 0.04 \\
\hline Education, culture, arts and broadcasting & 0.07 & 0.09 & 0.09 \\
\hline Scientific research and technical services & 0.03 & 0.03 & 0.02 \\
\hline Finance/insurance & 0.02 & 0.03 & 0.03 \\
\hline Government and Party organs, social organizations & 0.12 & 0.13 & 0.16 \\
\hline Agriculture/forestry/husbandry/fishing & 0.02 & 0.01 & 0.01 \\
\hline Other & 0.01 & 0.02 & 0.00 \\
\hline \multicolumn{4}{|l|}{ Firm/Organization Ownership } \\
\hline State Owned Enterprises & 0.82 & 0.70 & 0.57 \\
\hline Collectively Owned & 0.16 & 0.07 & 0.06 \\
\hline Private, Foreign, Joint Owned, and Others & 0.02 & 0.23 & 0.37 \\
\hline Ln(Wage) & 8.53 & 9.02 & 9.50 \\
\hline Standard Deviation of Ln(Wage) & 0.69 & 0.76 & 0.82 \\
\hline $50^{\text {th }}-10^{\text {th }}$ Percentile of Ln(Wage) & 0.81 & 0.92 & 0.99 \\
\hline $90^{\text {th }}-50^{\text {th }}$ Percentile of Ln(Wage $)$ & 0.62 & 0.73 & 0.89 \\
\hline No. of obs & 10974 & 9518 & 10827 \\
\hline
\end{tabular}


Table 2 Wage Determination in 1995, 2002, and 2007, OLS

\begin{tabular}{|c|c|c|c|c|c|c|}
\hline & 1995 & 2002 & 2007 & 1995 & 2002 & 2007 \\
\hline & $(1)$ & $(2)$ & (3) & (4) & $(5)$ & $(6)$ \\
\hline \multirow[t]{2}{*}{ Years of schooling } & $0.05^{* * *}$ & $0.08 * * *$ & $0.11 * * *$ & $0.03 * * *$ & $0.04 * * *$ & $0.07 * * *$ \\
\hline & $(0.00)$ & $(0.00)$ & $(0.00)$ & $(0.00)$ & $(0.00)$ & $(0.00)$ \\
\hline \multirow[t]{2}{*}{ Experience } & $0.05^{* * *}$ & $0.04 * * *$ & $0.04 * * *$ & $0.05 * * *$ & $0.04 * * *$ & $0.04 * * *$ \\
\hline & $(0.00)$ & $(0.00)$ & $(0.00)$ & $(0.00)$ & $(0.00)$ & $(0.00)$ \\
\hline \multirow[t]{2}{*}{ Experience squared/100 } & $-0.08 * * *$ & $-0.06 * * *$ & $-0.07 * * *$ & $-0.09 * * *$ & $-0.07 * * *$ & $-0.07 * * *$ \\
\hline & $(0.01)$ & $(0.01)$ & $(0.01)$ & $(0.01)$ & $(0.01)$ & $(0.01)$ \\
\hline \multirow[t]{2}{*}{ Female } & $-0.15^{* * *}$ & $-0.19 * * *$ & $-0.30 * * *$ & $-0.12 * * *$ & $-0.15 * * *$ & $-0.25 * * *$ \\
\hline & $(0.01)$ & $(0.01)$ & $(0.01)$ & $(0.01)$ & $(0.01)$ & $(0.01)$ \\
\hline \multicolumn{7}{|l|}{ Occupation } \\
\hline \multirow[t]{2}{*}{ Professional } & & & & -0.01 & $-0.05 * *$ & $-0.06^{*}$ \\
\hline & & & & $(0.02)$ & $(0.03)$ & $(0.03)$ \\
\hline \multirow[t]{2}{*}{ Ordinary Staff } & & & & $-0.12 * * *$ & $-0.16^{* * *}$ & $-0.18 * * *$ \\
\hline & & & & $(0.02)$ & $(0.02)$ & $(0.03)$ \\
\hline \multirow[t]{2}{*}{ Unskilled Worker } & & & & $-0.26 * * *$ & $-0.40 * * *$ & $-0.37^{* * *}$ \\
\hline & & & & $(0.02)$ & $(0.03)$ & $(0.04)$ \\
\hline \multirow[t]{2}{*}{ Skilled Worker } & & & & $-0.14 * * *$ & $-0.18 * * *$ & $-0.24 * * *$ \\
\hline & & & & $(0.02)$ & $(0.03)$ & $(0.03)$ \\
\hline \multirow[t]{2}{*}{ Others } & & & & $-0.21 * * *$ & $-0.76 * * *$ & $-0.42 * * *$ \\
\hline & & & & $(0.03)$ & $(0.04)$ & $(0.04)$ \\
\hline \multicolumn{7}{|l|}{ Industry } \\
\hline \multirow[t]{2}{*}{ Industry2 } & & & & $0.12 * *$ & 0.05 & $0.26^{* * *}$ \\
\hline & & & & $(0.05)$ & $(0.05)$ & $(0.06)$ \\
\hline \multirow[t]{2}{*}{ Industry3 } & & & & -0.01 & -0.03 & -0.02 \\
\hline & & & & $(0.03)$ & $(0.04)$ & $(0.04)$ \\
\hline \multirow[t]{2}{*}{ Industry4 } & & & & $0.08 * * *$ & $0.10^{* * *}$ & 0.04 \\
\hline & & & & $(0.03)$ & $(0.03)$ & $(0.02)$ \\
\hline \multirow[t]{2}{*}{ Industry5 } & & & & $-0.05 * * *$ & $-0.12 * * *$ & $-0.11 * * *$ \\
\hline & & & & $(0.02)$ & $(0.02)$ & $(0.03)$ \\
\hline \multirow[t]{2}{*}{ Industry6 } & & & & 0.00 & -0.02 & $-0.06^{* *}$ \\
\hline & & & & $(0.03)$ & $(0.02)$ & $(0.02)$ \\
\hline \multirow[t]{2}{*}{ Industry7 } & & & & $0.08^{* * *}$ & $0.18^{* * *}$ & -0.04 \\
\hline & & & & $(0.03)$ & $(0.03)$ & $(0.04)$ \\
\hline \multirow[t]{2}{*}{ Industry8 } & & & & $0.06 * * *$ & $0.16^{* * *}$ & 0.01 \\
\hline & & & & $(0.02)$ & $(0.03)$ & $(0.03)$ \\
\hline \multirow[t]{2}{*}{ Industry9 } & & & & $0.14 * * *$ & $0.19^{* * *}$ & $0.13^{* * *}$ \\
\hline & & & & $(0.04)$ & $(0.04)$ & $(0.05)$ \\
\hline Industry10 & & & & $0.30 * * *$ & $0.14 * * *$ & $0.17 * * *$ \\
\hline & & & & $(0.04)$ & $(0.04)$ & $(0.04)$ \\
\hline Industry11 & & & & $0.06 * * *$ & $0.12 * * *$ & 0.01 \\
\hline & & & & $(0.02)$ & $(0.02)$ & $(0.03)$ \\
\hline Industry12 & & & & 0.03 & 0.02 & 0.01 \\
\hline & & & & $(0.04)$ & $(0.06)$ & $(0.07)$ \\
\hline Industry13 & & & & -0.02 & 0.04 & - \\
\hline & & & & $(0.07)$ & $(0.05)$ & \\
\hline Ownership & & & & & & \\
\hline Collective Owned & & & & $-0.23 * * *$ & $-0.25 * * *$ & $-0.23^{* * *}$ \\
\hline & & & & $(0.02)$ & $(0.03)$ & $(0.03)$ \\
\hline Private or Joint Owned & & & & 0.03 & $-0.18^{* * *}$ & $-0.30 * * *$ \\
\hline & & & & $(0.04)$ & $(0.02)$ & $(0.02)$ \\
\hline R2_Adj & 0.26 & 0.24 & 0.29 & 0.30 & 0.34 & 0.36 \\
\hline $\mathrm{N}$ & 10974 & 9518 & 10827 & 10974 & 9518 & 10827 \\
\hline
\end{tabular}

Note: $*, * *$, and $* * *$ denote significance levels at $10 \%, 5 \%$, and $1 \%$ respectively. Standard errors are in parenthesis. Province dummies and constant term are controlled for. Managerial occupation and state owned enterprises are omitted groups. Industries 1 refers to Manufacturing (omitted group); Industry 2: Mining and geological survey and prospecting; Industry 3: Construction; Industry 4: Transportation, communications, posts and telecommunications; Industry 5: Commerce and trade, restaurants \& catering, materials supply; Industry 6: Real 
estate, public utilities, personal and consulting services; Industry 7: Health, physical culture and social welfare; Industry 8: Education, culture, arts and broadcasting; Industry 9: Scientific research and technical services; Industry 10: Finance and insurance; Industry 11: Government and Party organs, social organizations; Industry 12: Agriculture, forestry, husbandry, fishing; Industry 13: Other.

Table 3 Rank and Wage Determination in 1995 and 2002

\begin{tabular}{|c|c|c|c|c|c|c|c|c|c|c|}
\hline & \multicolumn{4}{|l|}{ OLS } & \multicolumn{6}{|c|}{ Quantile } \\
\hline & \multicolumn{2}{|c|}{ Full Sample } & \multicolumn{2}{|c|}{$\begin{array}{l}\text { Restricted } \\
\text { Sample }\end{array}$} & \multirow{2}{*}{\multicolumn{3}{|c|}{$\begin{array}{l}\text { Full Sample } \\
1995\end{array}$}} & \multirow{2}{*}{\multicolumn{3}{|c|}{$\frac{\text { Full Sample }}{2002}$}} \\
\hline & \multirow[t]{2}{*}{1995} & \multirow[t]{2}{*}{2002} & \multirow[t]{2}{*}{1995} & \multirow[t]{2}{*}{2002} & & & & & & \\
\hline & & & & & $\mathrm{Q} 10$ & Q50 & Q90 & $\overline{\mathrm{Q} 10}$ & Q50 & Q90 \\
\hline & (1) & (2) & (3) & (4) & (5) & (6) & (7) & (8) & (9) & (10) \\
\hline Senior Professional (Rank1) & $\begin{array}{l}0.19 * * * \\
(0.04)\end{array}$ & $\begin{array}{l}0.24 * * * \\
(0.04)\end{array}$ & & & $\begin{array}{l}0.21 * * * \\
(0.06)\end{array}$ & $\begin{array}{l}0.15^{* * *} \\
(0.03)\end{array}$ & $\begin{array}{l}0.12 * * * \\
(0.05)\end{array}$ & $\begin{array}{l}0.20^{* *} \\
(0.09)\end{array}$ & $\begin{array}{l}0.22^{* * *} \\
(0.04)\end{array}$ & $\begin{array}{l}0.24^{* * *} \\
(0.05)\end{array}$ \\
\hline $\begin{array}{l}\text { Middle Level Professional } \\
\text { (Rank2) }\end{array}$ & $0.11 * * *$ & $0.13^{* * *}$ & $-0.10^{* * *}$ & $-0.15 * * *$ & $0.16^{* * *}$ & $0.08^{* * *}$ & 0.04 & $0.15^{* *}$ & $0.10^{* * *}$ & $0.12 * * *$ \\
\hline & $(0.02)$ & $(0.03)$ & $(0.03)$ & $(0.03)$ & $(0.04)$ & $(0.02)$ & $(0.03)$ & $(0.06)$ & $(0.03)$ & $(0.03)$ \\
\hline Junior Professional (Rank3) & $\begin{array}{l}0.07 * * * \\
(0.02)\end{array}$ & $\begin{array}{l}0.04 \\
(0.03)\end{array}$ & $\begin{array}{l}-0.17^{* * *} \\
(0.03)\end{array}$ & $\begin{array}{l}-0.27 * * * \\
(0.04)\end{array}$ & $\begin{array}{l}0.11 * * * \\
(0.03)\end{array}$ & $\begin{array}{l}0.04 * * \\
(0.02)\end{array}$ & $\begin{array}{l}0.02 \\
(0.03)\end{array}$ & $\begin{array}{l}0.09 \\
(0.06)\end{array}$ & $\begin{array}{l}0.02 \\
(0.03)\end{array}$ & $\begin{array}{l}-0.00 \\
(0.04)\end{array}$ \\
\hline $\begin{array}{l}\text { Lowest Level Professional or } \\
\text { Technician (Rank4) }\end{array}$ & 0.03 & 0.01 & $-0.23 * * *$ & $-0.31 * * *$ & 0.04 & -0.00 & -0.01 & 0.04 & -0.04 & -0.04 \\
\hline & $(0.03)$ & $(0.05)$ & $(0.04)$ & $(0.05)$ & $(0.04)$ & $(0.02)$ & $(0.03)$ & $(0.11)$ & $(0.04)$ & $(0.06)$ \\
\hline Senior Official (Rank5) & $\begin{array}{l}0.19 \\
(0.17)\end{array}$ & $\begin{array}{l}-0.05 \\
(0.23)\end{array}$ & $\begin{array}{l}-0.03 \\
(0.14)\end{array}$ & $\begin{array}{l}-0.31 \\
(0.20)\end{array}$ & $\begin{array}{l}0.29 \\
(0.25)\end{array}$ & $\begin{array}{l}0.07 \\
(0.14)\end{array}$ & $\begin{array}{l}0.10 \\
(0.19)\end{array}$ & $\begin{array}{l}0.05 \\
(0.17)\end{array}$ & $\begin{array}{l}0.14 \\
(0.19)\end{array}$ & $\begin{array}{l}0.14 \\
(0.09)\end{array}$ \\
\hline Middle Level Official (Rank6) & $\begin{array}{l}0.15^{* * * *} \\
(0.05)\end{array}$ & $\begin{array}{l}0.31^{* * *} \\
(0.06)\end{array}$ & $\begin{array}{l}-0.04 \\
(0.05)\end{array}$ & $\begin{array}{l}0.07 \\
(0.06)\end{array}$ & $\begin{array}{l}0.15^{* *} \\
(0.08)\end{array}$ & $\begin{array}{l}0.16^{* * *} \\
(0.04)\end{array}$ & $\begin{array}{l}0.06 \\
(0.06)\end{array}$ & $\begin{array}{l}0.38^{* * *} \\
(0.12)\end{array}$ & $\begin{array}{l}0.30^{* * *} \\
(0.05)\end{array}$ & $\begin{array}{l}0.23 * * * \\
(0.07)\end{array}$ \\
\hline Junior Official (Rank7) & $\begin{array}{l}0.11^{* * * *} \\
(0.03)\end{array}$ & $\begin{array}{l}0.14^{* * *} \\
(0.04)\end{array}$ & $\begin{array}{l}-0.10^{* * *} \\
(0.04)\end{array}$ & $\begin{array}{l}-0.14 * * * \\
(0.04)\end{array}$ & $\begin{array}{l}0.17 * * * \\
(0.05)\end{array}$ & $\begin{array}{l}0.09^{* * *} \\
(0.03)\end{array}$ & $\begin{array}{l}0.02 \\
(0.04)\end{array}$ & $\begin{array}{l}0.22 * * * \\
(0.07)\end{array}$ & $\begin{array}{l}0.09^{* * *} \\
(0.03)\end{array}$ & $\begin{array}{l}0.11 * * \\
(0.04)\end{array}$ \\
\hline R2_Adj & 0.30 & 0.35 & 0.30 & 0.27 & & & & & & \\
\hline $\mathrm{N}$ & 10974 & 9518 & 4540 & 3542 & 10974 & 10974 & 10974 & 9518 & 9518 & 9518 \\
\hline
\end{tabular}

Note: *,*, and *** denote significance levels at $10 \%, 5 \%$, and $1 \%$ respectively. Standard errors are in parenthesis. Years of schooling, experience, experience squared, sex, occupation, industry, ownership, province, and constant term are controlled for in all the regressions. In columns 3 and 4, the omitted group is senior professionals; whereas in other columns the omitted group is the no-rank group (those who do not have titles). 
Table 4 Explanatory Power of Different Factors (Fields Decomposition, \%)

\begin{tabular}{lrrrrrr}
\hline & 1995 & 2002 & 2007 & 1995 & 2002 & 2007 \\
\cline { 2 - 7 } & $(1)$ & $(2)$ & $(3)$ & $(4)$ & $(5)$ & $(6)$ \\
\hline A & & & & & & \\
\hline Schooling Years & 2.0 & 4.7 & 8.7 & 6.6 & 13.5 & 24.3 \\
Experience & 8.3 & 4.2 & 1.7 & 27.1 & 12.0 & 4.8 \\
Sex & 1.4 & 1.5 & 2.9 & 4.7 & 4.5 & 8.2 \\
Region & 11.3 & 8.1 & 10.4 & 37.1 & 23.5 & 29.2 \\
Job characteristics & 7.4 & 16.1 & 12.0 & 24.4 & 46.6 & 33.5 \\
$\quad$ Occupation & 3.9 & 9.4 & 4.8 & 12.7 & 27.0 & 13.6 \\
\multicolumn{1}{c}{ Industry } & 1.3 & 3.5 & 1.8 & 4.2 & 10.0 & 4.9 \\
$\quad$ Ownership & 2.3 & 3.3 & 5.4 & 7.5 & 9.5 & 15.0 \\
Residual & 69.6 & 65.4 & 64.3 & & & \\
\hline B & & & & & & 12.2 \\
Schooling Years & 1.9 & 4.6 & 8.4 & 5.9 & 22.6 \\
Experience & 8.3 & 4.2 & 1.7 & 4.3 & 3.9 & 7.6 \\
Sex & 1.4 & 1.5 & 2.8 & 34.4 & 20.9 & 27.6 \\
Region & 11.2 & 7.9 & 10.3 & 30.0 & 52.0 & 37.6 \\
Job characteristics & 9.8 & 19.6 & 14.1 & & & \\
Residual & 67.4 & 62.3 & 62.6 & & & \\
\hline
\end{tabular}

Table 5 Explanatory Power of Different Factors Considering Rank (Fields Decomposition, \%)

\begin{tabular}{|c|c|c|c|c|c|c|c|c|}
\hline & \multicolumn{4}{|c|}{ Full Sample } & \multicolumn{4}{|c|}{ Restricted Sample } \\
\hline & 1995 & 2002 & 1995 & 2002 & 1995 & 2002 & 1995 & 2002 \\
\hline & $(1)$ & $(2)$ & (3) & (4) & $(5)$ & (6) & $(7)$ & (8) \\
\hline Schooling Years & 1.7 & 4.3 & 5.5 & 12.2 & 1.3 & 1.6 & 4.1 & 6.0 \\
\hline Experience & 7.8 & 3.8 & 25.6 & 11.0 & 5.5 & 2.9 & 17.7 & 10.5 \\
\hline Sex & 1.4 & 1.5 & 4.7 & 4.2 & 0.8 & 0.6 & 2.5 & 2.2 \\
\hline Region & 11.3 & 8.3 & 37.0 & 23.6 & 16.6 & 13.1 & 53.5 & 47.7 \\
\hline Job characteristics & 8.4 & 17.2 & 27.3 & 49.1 & 6.9 & 9.2 & 22.1 & 33.6 \\
\hline Occupation & 2.8 & 7.6 & 9.1 & 21.8 & 1.1 & 0.7 & 3.4 & 2.5 \\
\hline Industry & 1.2 & 3.2 & 3.8 & 9.0 & 1.5 & 3.6 & 4.8 & 13.2 \\
\hline Ownership & 2.3 & 3.3 & 7.4 & 9.3 & 1.5 & 0.9 & 4.9 & 3.4 \\
\hline Rank & 2.1 & 3.1 & 7.0 & 8.9 & 2.8 & 4.0 & 9.0 & 14.6 \\
\hline Residual & 69.4 & 65.0 & & & 69.0 & 72.6 & & \\
\hline
\end{tabular}


Table 6 Quantile Regression Results of Wage Determination

\begin{tabular}{|c|c|c|c|c|c|c|c|c|c|}
\hline & \multicolumn{3}{|l|}{1995} & \multicolumn{3}{|l|}{2002} & \multicolumn{3}{|l|}{2007} \\
\hline & $\mathrm{q} 10$ & $\mathrm{q} 50$ & q90 & $\mathrm{q} 10$ & $\mathrm{q} 50$ & q90 & $\mathrm{q} 10$ & $\mathrm{q} 50$ & q90 \\
\hline Years of schooling & $\begin{array}{l}0.03 * * * \\
(0.00)\end{array}$ & $\begin{array}{l}0.02 * * * \\
(0.00)\end{array}$ & $\begin{array}{l}0.02 * * * \\
(0.00)\end{array}$ & $\begin{array}{l}0.05^{* * *} \\
(0.01)\end{array}$ & $\begin{array}{l}0.04 * * * \\
(0.00)\end{array}$ & $\begin{array}{l}0.04^{* * * *} \\
(0.00)\end{array}$ & $\begin{array}{l}0.08 * * * \\
(0.01)\end{array}$ & $\begin{array}{l}0.07 * * * \\
(0.00)\end{array}$ & $\begin{array}{l}0.06^{* * *} \\
(0.00)\end{array}$ \\
\hline Experience & $\begin{array}{l}0.08^{* * *} \\
(0.00)\end{array}$ & $\begin{array}{l}0.04 * * * \\
(0.00)\end{array}$ & $\begin{array}{l}0.03 * * * \\
(0.00)\end{array}$ & $\begin{array}{l}0.07 * * * \\
(0.01)\end{array}$ & $\begin{array}{l}0.03 * * * \\
(0.00)\end{array}$ & $\begin{array}{l}0.02^{* * * *} \\
(0.00)\end{array}$ & $\begin{array}{l}0.05^{* * *} \\
(0.00)\end{array}$ & $\begin{array}{l}0.03 * * * \\
(0.00)\end{array}$ & $\begin{array}{l}0.03 * * * \\
(0.00)\end{array}$ \\
\hline Experience squared/100 & $\begin{array}{l}-0.14 * * * \\
(0.01)\end{array}$ & $\begin{array}{l}-0.06 * * * \\
(0.00)\end{array}$ & $\begin{array}{l}-0.03 * * * \\
(0.01)\end{array}$ & $\begin{array}{l}-0.13 * * * \\
(0.01)\end{array}$ & $\begin{array}{l}-0.05 * * * \\
(0.01)\end{array}$ & $\begin{array}{l}-0.03 * * * \\
(0.01)\end{array}$ & $\begin{array}{l}-0.10^{* * *} \\
(0.01)\end{array}$ & $\begin{array}{l}-0.06^{* * * *} \\
(0.01)\end{array}$ & $\begin{array}{l}-0.05 * * * \\
(0.01)\end{array}$ \\
\hline Female & $\begin{array}{l}-0.13 * * * \\
(0.02)\end{array}$ & $\begin{array}{l}-0.08^{* * *} \\
(0.01)\end{array}$ & $\begin{array}{l}-0.10^{* * * *} \\
(0.01)\end{array}$ & $\begin{array}{l}-0.17 * * * \\
(0.03)\end{array}$ & $\begin{array}{l}-0.14 * * * \\
(0.01)\end{array}$ & $\begin{array}{l}-0.12 * * * \\
(0.01)\end{array}$ & $\begin{array}{l}-0.29 * * * \\
(0.02)\end{array}$ & $\begin{array}{l}-0.26^{* * *} \\
(0.01)\end{array}$ & $\begin{array}{l}-0.21^{* * *} \\
(0.02)\end{array}$ \\
\hline \multicolumn{10}{|l|}{ Occupation } \\
\hline Professional & $\begin{array}{l}0.01 \\
(0.03)\end{array}$ & $\begin{array}{l}-0.00 \\
(0.02)\end{array}$ & $\begin{array}{l}-0.02 \\
(0.02)\end{array}$ & $\begin{array}{l}-0.06 \\
(0.05)\end{array}$ & $\begin{array}{l}-0.02 \\
(0.03)\end{array}$ & $\begin{array}{l}-0.05^{*} \\
(0.03)\end{array}$ & $\begin{array}{l}-0.02 \\
(0.06)\end{array}$ & $\begin{array}{l}-0.02 \\
(0.03)\end{array}$ & $\begin{array}{l}-0.06 \\
(0.04)\end{array}$ \\
\hline Ordinary Staff & $\begin{array}{l}-0.17 * * * \\
(0.03)\end{array}$ & $\begin{array}{l}-0.08 * * * \\
(0.02)\end{array}$ & $\begin{array}{l}-0.08 * * * \\
(0.02)\end{array}$ & $\begin{array}{l}-0.18^{* * *} \\
(0.05)\end{array}$ & $\begin{array}{l}-0.13 * * * \\
(0.03)\end{array}$ & $\begin{array}{l}-0.17 * * * \\
(0.03)\end{array}$ & $\begin{array}{l}-0.21 \text { *** } \\
(0.05)\end{array}$ & $\begin{array}{l}-0.17 * * * \\
(0.03)\end{array}$ & $\begin{array}{l}-0.17 * * * \\
(0.04)\end{array}$ \\
\hline Unskilled Worker & $\begin{array}{l}-0.38^{* * *} \\
(0.04)\end{array}$ & $\begin{array}{l}-0.20 * * * \\
(0.02)\end{array}$ & $\begin{array}{l}-0.15^{* * *} \\
(0.03)\end{array}$ & $\begin{array}{l}-0.47^{* * * *} \\
(0.06)\end{array}$ & $\begin{array}{l}-0.34 * * * \\
(0.03)\end{array}$ & $\begin{array}{l}-0.39 * * * \\
(0.03)\end{array}$ & $\begin{array}{l}-0.38^{* * *} \\
(0.06)\end{array}$ & $\begin{array}{l}-0.36^{* * * *} \\
(0.03)\end{array}$ & $\begin{array}{l}-0.30^{* * *} \\
(0.05)\end{array}$ \\
\hline Skilled Worker & $\begin{array}{l}-0.17 * * * \\
(0.03)\end{array}$ & $\begin{array}{l}-0.09 * * * \\
(0.02)\end{array}$ & $\begin{array}{l}-0.07 * * * \\
(0.03)\end{array}$ & $\begin{array}{l}-0.22 * * * \\
(0.06)\end{array}$ & $\begin{array}{l}-0.12 * * * \\
(0.03)\end{array}$ & $\begin{array}{l}-0.19 * * * \\
(0.03)\end{array}$ & $\begin{array}{l}-0.30^{* * *} \\
(0.06)\end{array}$ & $\begin{array}{l}-0.21 * * * \\
(0.03)\end{array}$ & $\begin{array}{l}-0.20 * * * \\
(0.05)\end{array}$ \\
\hline Others & $\begin{array}{l}-0.25^{* * *} \\
(0.04)\end{array}$ & $\begin{array}{l}-0.15^{* * *} \\
(0.03)\end{array}$ & $\begin{array}{l}-0.14 * * * \\
(0.03)\end{array}$ & $\begin{array}{l}-1.80 * * * \\
(0.08)\end{array}$ & $\begin{array}{l}-0.57 * * * \\
(0.04)\end{array}$ & $\begin{array}{l}-0.40 * * * \\
(0.05)\end{array}$ & $\begin{array}{l}-0.48 * * * \\
(0.08)\end{array}$ & $\begin{array}{l}-0.40 * * * \\
(0.04)\end{array}$ & $\begin{array}{l}-0.28 * * * \\
(0.06)\end{array}$ \\
\hline \multicolumn{10}{|l|}{ Industry } \\
\hline Industry2 & $\begin{array}{l}0.26^{* * *} \\
(0.08)\end{array}$ & $\begin{array}{l}0.11^{* *} \\
(0.05)\end{array}$ & $\begin{array}{l}0.02 \\
(0.06)\end{array}$ & $\begin{array}{l}0.09 \\
(0.11)\end{array}$ & $\begin{array}{l}0.07 \\
(0.05)\end{array}$ & $\begin{array}{l}-0.08 \\
(0.06)\end{array}$ & $\begin{array}{l}0.32 * * * \\
(0.10)\end{array}$ & $\begin{array}{l}0.27^{* * *} \\
(0.05)\end{array}$ & $\begin{array}{l}0.25^{* * *} \\
(0.07)\end{array}$ \\
\hline Industry3 & $\begin{array}{l}0.05 \\
(0.05)\end{array}$ & $\begin{array}{l}0.03 \\
(0.03)\end{array}$ & $\begin{array}{l}0.03 \\
(0.04)\end{array}$ & $\begin{array}{l}-0.20^{* *} \\
(0.08)\end{array}$ & $\begin{array}{l}-0.02 \\
(0.04)\end{array}$ & $\begin{array}{l}0.09 * * \\
(0.04)\end{array}$ & $\begin{array}{l}-0.09 \\
(0.07)\end{array}$ & $\begin{array}{l}0.05 \\
(0.04)\end{array}$ & $\begin{array}{l}-0.13 * * \\
(0.05)\end{array}$ \\
\hline Industry4 & $\begin{array}{l}0.08^{* *} \\
(0.04)\end{array}$ & $\begin{array}{l}0.09^{* * *} \\
(0.02)\end{array}$ & $\begin{array}{l}0.16^{* * *} \\
(0.03)\end{array}$ & $\begin{array}{l}0.10^{*} \\
(0.06)\end{array}$ & $\begin{array}{l}0.19 * * * \\
(0.03)\end{array}$ & $\begin{array}{l}0.17^{* * * *} \\
(0.03)\end{array}$ & $\begin{array}{l}-0.02 \\
(0.04)\end{array}$ & $\begin{array}{l}0.10^{* * *} \\
(0.02)\end{array}$ & $\begin{array}{l}-0.02 \\
(0.03)\end{array}$ \\
\hline Industry5 & $\begin{array}{l}-0.09^{* * *} \\
(0.03)\end{array}$ & $\begin{array}{l}-0.02 \\
(0.01)\end{array}$ & $\begin{array}{l}-0.02 \\
(0.02)\end{array}$ & $\begin{array}{l}-0.26^{* * *} \\
(0.05)\end{array}$ & $\begin{array}{l}-0.04 \\
(0.03)\end{array}$ & $\begin{array}{l}-0.02 \\
(0.03)\end{array}$ & $\begin{array}{l}-0.13^{* * *} \\
(0.05)\end{array}$ & $\begin{array}{l}0.01 \\
(0.02)\end{array}$ & $\begin{array}{l}-0.12 * * * \\
(0.03)\end{array}$ \\
\hline Industry6 & $\begin{array}{l}-0.08^{*} \\
(0.04)\end{array}$ & $\begin{array}{l}0.02 \\
(0.03)\end{array}$ & $\begin{array}{l}0.06^{*} \\
(0.03)\end{array}$ & $\begin{array}{l}-0.10^{* *} \\
(0.04)\end{array}$ & $\begin{array}{l}0.03 \\
(0.02)\end{array}$ & $\begin{array}{l}0.10^{* * *} \\
(0.02)\end{array}$ & $\begin{array}{l}-0.07^{*} \\
(0.04)\end{array}$ & $\begin{array}{l}-0.03 \\
(0.02)\end{array}$ & $\begin{array}{l}-0.08^{* *} \\
(0.03)\end{array}$ \\
\hline Industry7 & $\begin{array}{l}0.12 * * * \\
(0.04)\end{array}$ & $\begin{array}{l}0.11^{* * *} \\
(0.02)\end{array}$ & $\begin{array}{l}0.04 \\
(0.03)\end{array}$ & $\begin{array}{l}0.22 * * * \\
(0.07)\end{array}$ & $\begin{array}{l}0.26^{* * * *} \\
(0.03)\end{array}$ & $\begin{array}{l}0.16^{* * * *} \\
(0.03)\end{array}$ & $\begin{array}{l}-0.07 \\
(0.07)\end{array}$ & $\begin{array}{l}0.04 \\
(0.03)\end{array}$ & $\begin{array}{l}-0.04 \\
(0.05)\end{array}$ \\
\hline Industry8 & $\begin{array}{l}0.16^{* * *} \\
(0.04)\end{array}$ & $\begin{array}{l}0.06^{* * *} \\
(0.02)\end{array}$ & $\begin{array}{l}-0.01 \\
(0.03)\end{array}$ & $\begin{array}{l}0.14^{* *} \\
(0.06)\end{array}$ & $\begin{array}{l}0.23 * * * \\
(0.03)\end{array}$ & $\begin{array}{l}0.17 * * * \\
(0.03)\end{array}$ & $\begin{array}{l}0.03 \\
(0.05)\end{array}$ & $\begin{array}{l}0.08 * * * \\
(0.03)\end{array}$ & $\begin{array}{l}-0.07 * \\
(0.04)\end{array}$ \\
\hline Industry9 & $\begin{array}{l}0.22 * * * \\
(0.05)\end{array}$ & $\begin{array}{l}0.14 * * * \\
(0.03)\end{array}$ & $\begin{array}{l}0.04 \\
(0.04)\end{array}$ & $\begin{array}{l}0.07 \\
(0.09)\end{array}$ & $\begin{array}{l}0.24 * * * \\
(0.04)\end{array}$ & $\begin{array}{l}0.28^{* * *} \\
(0.04)\end{array}$ & $\begin{array}{l}0.15^{*} \\
(0.08)\end{array}$ & $\begin{array}{l}0.20 * * * \\
(0.04)\end{array}$ & $\begin{array}{l}-0.04 \\
(0.06)\end{array}$ \\
\hline Industry10 & $\begin{array}{l}0.29 * * * \\
(0.06)\end{array}$ & $\begin{array}{l}0.31 * * * \\
(0.03)\end{array}$ & $\begin{array}{l}0.26^{* * * *} \\
(0.04)\end{array}$ & $\begin{array}{l}0.24 * * * \\
(0.08)\end{array}$ & $\begin{array}{l}0.19^{* * *} \\
(0.04)\end{array}$ & $\begin{array}{l}0.18^{* * *} \\
(0.04)\end{array}$ & $\begin{array}{l}0.18^{* *} \\
(0.07)\end{array}$ & $\begin{array}{l}0.18^{* * *} \\
(0.04)\end{array}$ & $\begin{array}{l}0.08 \\
(0.05)\end{array}$ \\
\hline Industry11 & $\begin{array}{l}0.16^{* * *} \\
(0.03)\end{array}$ & $\begin{array}{l}0.06^{* * *} \\
(0.02)\end{array}$ & $\begin{array}{l}-0.03 \\
(0.02)\end{array}$ & $\begin{array}{l}0.15^{* * *} \\
(0.05)\end{array}$ & $\begin{array}{l}0.19 * * * \\
(0.03)\end{array}$ & $\begin{array}{l}0.13 * * * \\
(0.03)\end{array}$ & $\begin{array}{l}0.02 \\
(0.05)\end{array}$ & $\begin{array}{l}0.08 * * * \\
(0.02)\end{array}$ & $\begin{array}{l}-0.07 * * \\
(0.03)\end{array}$ \\
\hline Industry12 & $\begin{array}{l}0.05 \\
(0.06)\end{array}$ & $\begin{array}{l}0.03 \\
(0.04)\end{array}$ & $\begin{array}{l}0.12 * * * \\
(0.05)\end{array}$ & $\begin{array}{l}0.06 \\
(0.12)\end{array}$ & $\begin{array}{l}0.07 \\
(0.06)\end{array}$ & $\begin{array}{l}-0.01 \\
(0.06)\end{array}$ & $\begin{array}{l}0.11 \\
(0.12)\end{array}$ & $\begin{array}{l}0.08 \\
(0.06)\end{array}$ & $\begin{array}{l}-0.15^{*} \\
(0.09)\end{array}$ \\
\hline Industry13 & $\begin{array}{l}-0.06 \\
(0.10)\end{array}$ & $\begin{array}{l}-0.02 \\
(0.06)\end{array}$ & $\begin{array}{l}0.12 \\
(0.07)\end{array}$ & $\begin{array}{l}0.01 \\
(0.10)\end{array}$ & $\begin{array}{l}0.07 \\
(0.05)\end{array}$ & $\begin{array}{l}0.01 \\
(0.05)\end{array}$ & & & \\
\hline \multicolumn{10}{|l|}{ Ownership } \\
\hline Collective Owned & $\begin{array}{l}-0.31 * * * \\
(0.02)\end{array}$ & $\begin{array}{l}-0.22 * * * \\
(0.01)\end{array}$ & $\begin{array}{l}-0.19 * * * \\
(0.02)\end{array}$ & $\begin{array}{l}-0.27 * * * \\
(0.06)\end{array}$ & $\begin{array}{l}-0.27 * * * \\
(0.03)\end{array}$ & $\begin{array}{l}-0.16^{* * *} \\
(0.03)\end{array}$ & $\begin{array}{l}-0.17 * * * \\
(0.05)\end{array}$ & $\begin{array}{l}-0.24 * * * \\
(0.03)\end{array}$ & $\begin{array}{l}-0.26 * * * \\
(0.04)\end{array}$ \\
\hline $\begin{array}{l}\text { Private or Joint } \\
\text { Owned }\end{array}$ & $\begin{array}{l}-0.10 \\
(0.06)\end{array}$ & $\begin{array}{l}0.07 * * \\
(0.03)\end{array}$ & $\begin{array}{l}0.10 * * \\
(0.04)\end{array}$ & $\begin{array}{l}-0.26 * * * \\
(0.04)\end{array}$ & $\begin{array}{l}-0.11 * * * \\
(0.02)\end{array}$ & $\begin{array}{l}-0.05 * * * \\
(0.02)\end{array}$ & $\begin{array}{l}-0.30 * * * \\
(0.03)\end{array}$ & $\begin{array}{l}-0.25 * * * \\
(0.01)\end{array}$ & $\begin{array}{l}-0.23 * * * \\
(0.02)\end{array}$ \\
\hline $\mathrm{N}$ & 10974 & 10974 & 10974 & 9518 & 9518 & 9518 & 10827 & 10827 & 10827 \\
\hline
\end{tabular}

Note: ${ }^{*}, * *$ and $* * *$ denote significance levels at $10 \%, 5 \%$, and $1 \%$ respectively. Standard errors are in parenthesis. Province dummies and constant term are controlled for. Managerial occupation and state owned enterprises are omitted groups. Industries 1 refers to Manufacturing 
(omitted group); Industry 2: Mining and geological survey and prospecting; Industry 3: Construction; Industry 4: Transportation, communications, posts and telecommunications; Industry 5: Commerce and trade, restaurants \& catering, materials supply; Industry 6: Real estate, public utilities, personal and consulting services; Industry 7: Health, physical culture and social welfare; Industry 8: Education, culture, arts and broadcasting; Industry 9: Scientific research and technical services; Industry 10: Finance and insurance; Industry 11: Government and Party organs, social organizations; Industry 12: Agriculture, forestry, husbandry, fishing; Industry 13: Other.

Table 7 Actual Inequalities and Counterfactuals Constructed Using DFL Approach

\begin{tabular}{|c|c|c|c|c|c|c|}
\hline & \multicolumn{3}{|c|}{ Log (wage) } & \multicolumn{3}{|c|}{ Residual of Log (wage) } \\
\hline & P95 & P02 & P07 & P95 & $\mathrm{P} 02$ & P07 \\
\hline & (1) & (2) & (3) & (4) & (5) & (6) \\
\hline \multicolumn{7}{|c|}{ A: $90^{\text {th }}$ percentile $-10^{\text {th }}$ percentile } \\
\hline d9010_S95 & 1.433 & 1.593 & 1.761 & 1.152 & 1.347 & 1.428 \\
\hline d9010_S02 & 1.554 & 1.653 & 1.849 & 1.236 & 1.394 & 1.445 \\
\hline d9010_S07 & 1.674 & 1.710 & 1.878 & 1.321 & 1.449 & 1.474 \\
\hline \multicolumn{7}{|c|}{ B: $50^{\text {th }}$ percentile $-10^{\text {th }}$ percentile } \\
\hline d5010_S95 & 0.808 & 0.871 & 0.935 & 0.636 & 0.758 & 0.740 \\
\hline d5010_S02 & 0.871 & 0.922 & 0.978 & 0.666 & 0.792 & 0.753 \\
\hline d5010_S07 & 0.957 & 0.962 & 0.986 & 0.736 & 0.832 & 0.792 \\
\hline \multicolumn{7}{|c|}{$\mathrm{C}: 90^{\text {th }}$ percentile $-50^{\text {th }}$ percentile } \\
\hline d9050_S95 & 0.624 & 0.722 & 0.826 & 0.517 & 0.589 & 0.688 \\
\hline d9050_S02 & 0.684 & 0.731 & 0.871 & 0.569 & 0.601 & 0.692 \\
\hline$\underline{\text { d9050_S07 }}$ & 0.717 & 0.748 & 0.892 & 0.585 & 0.617 & 0.682 \\
\hline \multicolumn{7}{|c|}{ D: Variance of Log Wage } \\
\hline var_S95 & 0.475 & 0.503 & 0.510 & 0.349 & 0.382 & 0.351 \\
\hline var_S02 & 0.599 & 0.578 & 0.608 & 0.424 & 0.437 & 0.422 \\
\hline var_S07 & 0.742 & 0.598 & 0.669 & 0.500 & 0.460 & 0.477 \\
\hline \multicolumn{7}{|c|}{ E: Between-job Variance } \\
\hline varxb_S95 & 0.065 & 0.124 & 0.099 & 0.024 & 0.055 & 0.031 \\
\hline varxb_S02 & 0.149 & 0.140 & 0.133 & 0.071 & 0.065 & 0.044 \\
\hline varxb_S07 & 0.258 & 0.129 & 0.135 & 0.117 & 0.063 & 0.047 \\
\hline \multicolumn{7}{|c|}{ F: Within-job Variance } \\
\hline varres_S95 & 0.409 & 0.379 & 0.411 & 0.325 & 0.327 & 0.320 \\
\hline varres_S02 & 0.450 & 0.438 & 0.475 & 0.353 & 0.372 & 0.378 \\
\hline varres_S07 & 0.484 & 0.469 & 0.535 & 0.383 & 0.397 & 0.430 \\
\hline
\end{tabular}

Note: Residual of Log (wage) is obtained by first running regressions of Log (wage) on schooling years, experience, experience squared, sex, and province dummy variables, and then predicting wage residuals. P95, P02, and P07 denote skill prices of 1995, 2002, and 2007, respectively; whereas S95, S02, and S07 denote skill distribution of 1995, 2002, and 2007, respectively. 


\section{Appendix}

Table 8 Regional Distribution of Observations

\begin{tabular}{|c|c|c|c|c|c|c|c|c|c|}
\hline & \multicolumn{3}{|c|}{1995} & \multicolumn{3}{|c|}{2002} & \multicolumn{3}{|c|}{2007} \\
\hline & East & Central & West & East & Central & West & East & Central & West \\
\hline \multicolumn{10}{|l|}{ By Occupation (\%) } \\
\hline Managerial (Head/Unit Head) & 11.2 & 11.9 & 12.2 & 10.0 & 12.1 & 11.1 & 4.6 & 6.0 & 5.3 \\
\hline Professional & 21.9 & 19.6 & 27.4 & 19.4 & 24.5 & 22.6 & 20.6 & 18.9 & 18.4 \\
\hline Ordinary Staff & 18.6 & 23.0 & 22.2 & 22.0 & 20.3 & 21.2 & 36.5 & 35.0 & 33.9 \\
\hline Unskilled Worker & 18.3 & 20.2 & 11.5 & 25.3 & 19.2 & 20.6 & 17.5 & 13.2 & 19.0 \\
\hline Skilled Worker & 24.5 & 19.3 & 22.4 & 18.5 & 20.0 & 20.7 & 17.3 & 24.2 & 18.1 \\
\hline Others & 5.5 & 6.1 & 4.4 & 4.8 & 3.8 & 3.8 & 3.6 & 2.8 & 5.4 \\
\hline \multicolumn{10}{|l|}{ By Industry (\%) } \\
\hline Manufacturing & 43.5 & 43.3 & 38.9 & 24.6 & 26.9 & 27.2 & 18.2 & 22.2 & 19.3 \\
\hline Mining and geological survey & 0.3 & 1.0 & 2.1 & 0.5 & 3.4 & 1.0 & 0.9 & 2.4 & 0.9 \\
\hline Construction & 3.1 & 2.1 & 3.7 & 3.6 & 2.6 & 3.9 & 3.4 & 2.8 & 2.9 \\
\hline $\begin{array}{l}\text { Transportation, communications, } \\
\text { posts and telecommunications }\end{array}$ & 5.8 & 4.6 & 4.8 & 9.8 & 7.0 & 6.5 & 12.2 & 8.6 & 8.8 \\
\hline $\begin{array}{l}\text { Commerce and trade, restaurants \& } \\
\text { catering, materials supply }\end{array}$ & 14.5 & 13.5 & 14.5 & 11.8 & 9.0 & 9.9 & 15.7 & 11.0 & 13.3 \\
\hline $\begin{array}{l}\text { Real estate, public utilities, personal } \\
\text { and consulting services }\end{array}$ & 4.9 & 3.1 & 2.8 & 17.7 & 13.1 & 11.7 & 15.8 & 15.7 & 18.9 \\
\hline $\begin{array}{l}\text { Health, physical culture and } \\
\text { social welfare }\end{array}$ & 4.4 & 4.6 & 5.2 & 3.7 & 6.6 & 5.7 & 3.8 & 4.5 & 4.6 \\
\hline Education, culture, arts and broadcasting & 7.3 & 8.1 & 6.5 & 7.4 & 11.2 & 9.8 & 8.6 & 9.6 & 8.9 \\
\hline Scientific research and technical services & 2.3 & 1.7 & 3.9 & 3.1 & 2.1 & 3.0 & 2.3 & 2.6 & 2.2 \\
\hline Finance/insurance & 1.7 & 2.3 & 2.0 & 3.3 & 2.9 & 2.0 & 2.8 & 3.4 & 3.2 \\
\hline $\begin{array}{l}\text { Government and Party organs, } \\
\text { social organizations }\end{array}$ & 9.3 & 14.0 & 13.1 & 10.7 & 12.3 & 15.5 & 16.0 & 16.5 & 15.3 \\
\hline Agriculture/forestry/husbandry/fishing & 1.9 & 1.4 & 2.0 & 0.9 & 0.9 & 2.2 & 0.4 & 0.8 & 1.8 \\
\hline Other & 1.1 & 0.2 & 0.4 & 2.8 & 2.0 & 1.6 & 0.0 & 0.0 & 0.0 \\
\hline \multicolumn{10}{|l|}{ By Ownership (\%) } \\
\hline State Owned Enterprises & 77.9 & 84.3 & 86.0 & 63.5 & 75.7 & 72.8 & 50.4 & 67.1 & 56.4 \\
\hline Collectively Owned & 18.3 & 14.7 & 12.9 & 9.1 & 5.6 & 6.4 & 6.7 & 6.2 & 4.8 \\
\hline $\begin{array}{l}\text { Private, Foreign, Joint Owned, } \\
\text { and Others }\end{array}$ & 3.8 & 1.0 & 1.1 & 27.4 & 18.7 & 20.8 & 42.9 & 26.7 & 38.9 \\
\hline No. of Obs. & 4,073 & 3,923 & 2,978 & 3,668 & 3,279 & 2,571 & 4,588 & 3,121 & 3,118 \\
\hline
\end{tabular}


Table 9 Working Time in 1995 and 2002

\begin{tabular}{|c|c|c|c|c|c|c|c|c|c|c|}
\hline & \multicolumn{4}{|l|}{1995} & \multicolumn{6}{|l|}{2002} \\
\hline & \multicolumn{2}{|c|}{ Days per week } & \multicolumn{2}{|c|}{ Hours per day } & \multicolumn{2}{|c|}{ Months per year } & \multicolumn{2}{|c|}{ Days per month } & \multicolumn{2}{|c|}{ Hours per day } \\
\hline & Mean & SD & Mean & $\mathrm{SD}$ & Mean & SD & Mean & SD & Mean & SD \\
\hline \multicolumn{11}{|l|}{ By Occupation } \\
\hline Managerial (Head/Unit Head) & 5.4 & 0.6 & 7.9 & 0.9 & 11.9 & 0.9 & 22.7 & 2.8 & 8.0 & 1.1 \\
\hline Professional & 5.3 & 0.6 & 7.7 & 0.9 & 11.6 & 1.5 & 22.5 & 3.4 & 8.0 & 1.3 \\
\hline Ordinary Staff & 5.4 & 0.6 & 7.7 & 0.9 & 11.8 & 1.2 & 22.5 & 3.1 & 7.9 & 1.2 \\
\hline Unskilled Worker & 5.6 & 0.7 & 7.7 & 1.1 & 11.4 & 1.8 & 24.1 & 4.2 & 8.3 & 1.8 \\
\hline Skilled Worker & 5.5 & 0.7 & 7.8 & 1.0 & 11.6 & 1.5 & 23.0 & 3.8 & 8.2 & 1.6 \\
\hline Others & 5.7 & 0.8 & 7.6 & 1.2 & 11.3 & 2.1 & 25.5 & 5.1 & 8.8 & 2.3 \\
\hline \multicolumn{11}{|l|}{ By Industry } \\
\hline Manufacturing & 5.5 & 0.7 & 7.7 & 1.0 & 11.7 & 1.5 & 23.1 & 3.6 & 8.1 & 1.2 \\
\hline Mining and geological survey & 5.3 & 0.5 & 7.7 & 0.8 & 11.6 & 1.7 & 22.8 & 3.4 & 8.2 & 0.9 \\
\hline Construction & 5.5 & 0.6 & 7.8 & 0.8 & 11.5 & 1.8 & 23.3 & 3.9 & 8.1 & 1.2 \\
\hline $\begin{array}{l}\text { Transportation, communications, } \\
\text { posts and telecommunications }\end{array}$ & 5.5 & 0.7 & 7.8 & 1.0 & 11.7 & 1.5 & 23.0 & 4.2 & 8.3 & 1.9 \\
\hline $\begin{array}{l}\text { Commerce and trade, restaurants \& } \\
\text { catering, materials supply }\end{array}$ & 5.6 & 0.7 & 7.6 & 1.0 & 11.4 & 1.9 & 25.0 & 4.3 & 8.3 & 1.8 \\
\hline $\begin{array}{l}\text { Real estate, public utilities, personal } \\
\text { and consulting services }\end{array}$ & 5.5 & 0.7 & 7.7 & 1.0 & 11.6 & 1.5 & 23.4 & 3.7 & 8.2 & 1.8 \\
\hline $\begin{array}{l}\text { Health, physical culture and } \\
\text { social welfare }\end{array}$ & 5.4 & 0.6 & 7.7 & 0.9 & 11.8 & 1.1 & 22.8 & 3.2 & 7.9 & 1.3 \\
\hline Education, culture, arts and broadcasting & 5.3 & 0.6 & 7.7 & 1.1 & 11.3 & 1.6 & 22.3 & 3.3 & 8.0 & 1.5 \\
\hline Scientific research and technical services & 5.3 & 0.5 & 7.8 & 0.9 & 11.7 & 1.3 & 22.3 & 2.8 & 8.0 & 0.9 \\
\hline Finance/insurance & 5.4 & 0.6 & 7.8 & 1.1 & 11.5 & 1.9 & 22.8 & 3.6 & 7.8 & 1.6 \\
\hline $\begin{array}{l}\text { Government and Party organs, } \\
\text { social organizations }\end{array}$ & 5.3 & 0.5 & 7.8 & 0.9 & 11.9 & 0.8 & 22.2 & 3.1 & 8.0 & 1.2 \\
\hline Agriculture/forestry/husbandry/fishing & 5.3 & 0.5 & 7.8 & 1.0 & 11.8 & 0.7 & 22.5 & 3.3 & 8.3 & 1.7 \\
\hline Other & 5.3 & 0.6 & 7.7 & 1.0 & 11.2 & 2.3 & 22.9 & 5.0 & 8.3 & 2.6 \\
\hline \multicolumn{11}{|l|}{ By Ownership } \\
\hline State Owned Enterprises & 5.4 & 0.6 & 7.7 & 0.9 & 11.7 & 1.4 & 22.6 & 3.4 & 8.0 & 1.4 \\
\hline Collectively Owned & 5.6 & 0.8 & 7.7 & 1.1 & 11.7 & 1.4 & 23.3 & 3.7 & 8.1 & 1.3 \\
\hline $\begin{array}{l}\text { Private, Foreign, Joint Owned, } \\
\text { and Others }\end{array}$ & 5.8 & 0.6 & 8.1 & 1.2 & 11.4 & 1.9 & 24.7 & 4.3 & 8.4 & 1.8 \\
\hline Total Obs. & 5.5 & 0.6 & 7.7 & 1.0 & 11.6 & 1.5 & 23.1 & 3.7 & 8.1 & 1.5 \\
\hline
\end{tabular}

Table 10 Number of Observations in Domestic and Foreign (or Joint Venture) Firms

\begin{tabular}{|c|c|c|c|c|}
\hline & \multicolumn{2}{|c|}{1995} & \multicolumn{2}{|c|}{2002} \\
\hline & Domestic & $\begin{array}{c}\text { Foreign or } \\
\text { Joint Venture }\end{array}$ & Domestic & $\begin{array}{c}\text { Foreign or } \\
\text { Joint Venture }\end{array}$ \\
\hline \multicolumn{5}{|l|}{ Industry } \\
\hline Manufacturing & 4,545 & 83 & 2,374 & 112 \\
\hline Mining and geological survey & 115 & 0 & 158 & 0 \\
\hline Construction & 319 & 1 & 316 & 2 \\
\hline Transportation, communications, posts and telecommunications & 555 & 3 & 750 & 9 \\
\hline Commerce and trade, restaurants \& catering, materials supply & 1,513 & 39 & 947 & 36 \\
\hline Real estate, public utilities, personal and consulting services & 402 & 3 & 1,353 & 26 \\
\hline Health, physical culture and social welfare & 513 & 0 & 495 & 3 \\
\hline Education, culture, arts and broadcasting & 813 & 0 & 887 & 4 \\
\hline Scientific research and technical services & 274 & 1 & 249 & 9 \\
\hline Finance/insurance & 218 & 2 & 266 & 1 \\
\hline Government and Party organs, social organizations & 1,317 & 1 & 1,192 & 2 \\
\hline Agriculture/forestry/husbandry/fishing & 191 & 0 & 120 & 1 \\
\hline Other & 61 & 5 & 198 & 8 \\
\hline Total & 10,836 & 138 & 9,305 & 213 \\
\hline
\end{tabular}


Table 11 Reweighting Decomposition of Wage Inequality by Gender

\begin{tabular}{|c|c|c|c|c|c|c|c|c|c|c|c|c|}
\hline & \multicolumn{6}{|l|}{ Male } & \multicolumn{6}{|c|}{ Female } \\
\hline & \multicolumn{3}{|c|}{ Log (wage) } & \multicolumn{3}{|c|}{ Residual of Log (wage) } & \multicolumn{3}{|c|}{ Log (wage) } & \multicolumn{3}{|c|}{ Residual of Log (wage) } \\
\hline & P95 & & 97 & P95 & P02 & P07 & P95 & $\mathrm{P} 02$ & P07 & P95 & P02 & P07 \\
\hline & (1) & & ) & (4) & (5) & (6) & (7) & (8) & (9) & $(10)$ & (11) & $(12)$ \\
\hline \multicolumn{13}{|c|}{ A: $90^{\text {th }}$ percentile $-10^{\text {th }}$ percentile } \\
\hline d9010_S95 & 1.309 & 1.465 & 1.645 & 1.082 & 21.266 & 1.362 & 1.502 & 1.644 & 1.790 & 1.202 & 1.411 & 1.489 \\
\hline d9010_S02 & 1.404 & 1.551 & 1.746 & 1.139 & $\quad 1.333$ & 1.397 & 1.640 & 1.697 & 1.795 & 1.263 & 1.447 & 1.490 \\
\hline d9010_S07 & 1.470 & 1.596 & 1.810 & 1.139 & $9 \quad 1.378$ & 1.436 & 1.712 & 1.754 & 1.805 & 1.358 & 1.503 & 1.512 \\
\hline \multicolumn{13}{|c|}{$\mathrm{B}: 50^{\text {th }}$ percentile $-10^{\text {th }}$ percentile } \\
\hline d5010_S95 & 0.706 & 0.797 & 0.848 & 0.584 & 0.702 & 0.706 & 0.873 & 0.865 & 1.033 & 0.691 & 0.792 & 0.746 \\
\hline d5010_S02 & 0.718 & 0.867 & 0.910 & 0.607 & 0.763 & 0.742 & 0.921 & 0.911 & 0.965 & 0.690 & 0.815 & 0.762 \\
\hline d5010_S07 & 0.721 & 0.893 & 0.939 & 0.611 & 0.793 & 0.778 & 0.970 & 0.941 & 0.928 & 0.725 & 0.863 & 0.794 \\
\hline \multicolumn{13}{|c|}{ C: $90^{\text {th }}$ percentile $-50^{\text {th }}$ percentile } \\
\hline d9050_S95 & 0.602 & 0.667 & 0.796 & 0.498 & 0.565 & 0.656 & 0.629 & 0.779 & 0.757 & 0.511 & 0.619 & 0.742 \\
\hline d9050_S02 & 0.686 & 0.684 & 0.837 & 0.532 & 0.569 & 0.655 & 0.719 & 0.787 & 0.830 & 0.573 & 0.632 & 0.728 \\
\hline d9050_S07 & 0.749 & 0.702 & 0.871 & 0.528 & 0.585 & 0.658 & 0.742 & 0.813 & 0.877 & 0.633 & 0.640 & 0.718 \\
\hline \multicolumn{13}{|c|}{ D: Variance of Log Wage } \\
\hline var_S95 & 0.396 & 0.447 & 0.456 & 0.293 & 0.356 & 0.329 & 0.537 & 0.540 & 0.506 & 0.406 & 0.407 & 0.370 \\
\hline var_S02 & 0.648 & 0.541 & 0.579 & 0.496 & 0.421 & 0.418 & 0.552 & 0.594 & 0.578 & 0.378 & 0.452 & 0.426 \\
\hline var_S07 & 0.807 & 0.538 & 0.640 & 0.631 & 0.422 & 0.472 & 0.666 & 0.631 & 0.647 & 0.364 & 0.492 & 0.476 \\
\hline \multicolumn{13}{|c|}{ E: Between-job Variance } \\
\hline varxb_S95 & 0.054 & 0.104 & 0.085 & 0.026 & 0.054 & 0.035 & 0.078 & 0.149 & 0.129 & 0.035 & 0.073 & 0.041 \\
\hline varxb_S02 & 0.263 & 0.125 & 0.132 & 0.179 & 0.067 & 0.053 & 0.155 & 0.159 & 0.132 & 0.067 & 0.077 & 0.047 \\
\hline varxb_S07 & 0.280 & 0.106 & 0.126 & 0.183 & 0.060 & 0.054 & 0.340 & 0.159 & 0.135 & 0.112 & 0.084 & 0.054 \\
\hline \multicolumn{13}{|c|}{ F: Within-job Variance } \\
\hline varres_S95 & 0.341 & 0.343 & 0.371 & 0.266 & 0.301 & 0.294 & 0.459 & 0.391 & 0.377 & 0.371 & 0.334 & 0.329 \\
\hline varres_S02 & 0.385 & 0.415 & 0.448 & 0.317 & 0.354 & 0.364 & 0.397 & 0.434 & 0.446 & 0.311 & 0.375 & 0.378 \\
\hline varres_S07 & 0.527 & 0.432 & 0.515 & 0.449 & 0.363 & 0.418 & 0.326 & 0.472 & 0.512 & 0.252 & 0.408 & 0.422 \\
\hline
\end{tabular}

Note: Residual of Log (wage) is obtained by first running regressions of Log (wage) on schooling years, experience, experience squared, sex, and province dummy variables, and then predicting wage residuals. P95, P02, and P07 denote skill prices of 1995, 2002, and 2007, respectively; whereas S95, S02, and S07 denote skill distribution of 1995, 2002, and 2007, respectively. 